Old Dominion University

ODU Digital Commons

OES Faculty Publications

Ocean \& Earth Sciences

$12-2012$

\title{
Glacial Shortcut of Arctic Sea-Ice Transport
}

Michael Stärz

Xun Gong

Rüdiger Stein

Dennis A. Darby

Frank Kauker

See next page for additional authors

Follow this and additional works at: https://digitalcommons.odu.edu/oeas_fac_pubs

Part of the Geochemistry Commons, Geophysics and Seismology Commons, Glaciology Commons, and the Oceanography Commons 
Authors

Michael Stärz, Xun Gong, Rüdiger Stein, Dennis A. Darby, Frank Kauker, and Gerrit Lohmann 
Title: Glacial shortcut of Arctic sea-ice transport

Authors:

Michael Stärz ${ }^{1,2 *}$

*corresponding author

${ }^{1}$ contact: Alfred Wegener Institute for Polar and Marine Research, Bussestraße 24, D-27570

Bremerhaven, Germany

e-mail: michael.staerz@awi.de

phone: $+49(471) 4831-1880$

${ }^{2}$ Senckenberg Research Institute und Nature Museum, LOEWE - Biodiversity and Climate Research Centre BiK-F, Senckenberganlage 25, D-60325 Frankfurt am Main, Germany

\section{Xun Gong}

contact: Alfred Wegener Institute for Polar and Marine Research, Bussestraße 24, D-27570

Bremerhaven

e-mail: GongXun.Allen@awi.de

phone: $+49(471) 4831-1880$

Rüdiger Stein, Professor

contact: Alfred Wegener Institute for Polar and Marine Research, Am Alten Hafen 26, D-27568

Bremerhaven

e-mail: Ruediger.Stein@awi.de

phone: $+49(471) 4831-1576$

Dennis A Darby, Professor

contact: Old Dominion University, 4600 Elkhorn Ave., Norfolk, VA 23529-0276, USA

e-mail: ddarby@ odu.edu 
phone: 757-683-4701

Frank Kauker, Dr.

contact: Alfred Wegener Institute for Polar and Marine Research, Bussestraße 24, D-27570

Bremerhaven

e-mail: Frank.Kauker@awi.de

phone: +49(471)4831-1804

Gerrit Lohmann, Professor

contact: Alfred Wegener Institute for Polar and Marine Research, Bussestraße 24, D-27570

Bremerhaven

e-mail: Gerrit.Lohmann@awi.de

phone: +49(471)4831-1758

Keywords: Last Glacial Maximum, regional ocean sea-ice model, Arctic Ocean, CLIMAP, GLAMAP, NAOSIM, sea-ice drift 


\section{$1 \quad$ Abstract}

2 Due to the lack of data, the extent, thickness and drift patterns of sea ice and icebergs in the glacial

3 Arctic remains poorly constrained. Earlier studies are contradictory proposing either a cessation of

4 the marine cryosphere or an ice drift system operating like present-day. Here we examine the

5 marine Arctic cryosphere during the Last Glacial Maximum (LGM) using a high-resolution,

6 regional ocean-sea ice model. Whereas modern sea ice in the western Arctic Basin can circulate in

7 the Beaufort Gyre for decades, our model studies present an extreme shortcut of glacial ice drift. In

8 more detail, our results show a clockwise sea-ice drift in the western Arctic Basin that merges into a

9 direct trans-Arctic path towards Fram Strait. This is consistent with dated ice plough marks on the

10 seafloor, which show the orientation of iceberg drift in this direction. Also ice-transported iron-

11 oxide grains deposited in Fram Strait, can be matched by their chemical composition to similar

12 grains found in potential sources from the entire circum-Arctic. The model results indicate that the

13 pattern of Arctic sea-ice drift during the LGM is established by wind fields and seems to be a

14 general feature of the glacial ocean. Our model results do not indicate a cessation in ice drift during

15 the LGM. 
17 The nature of the Arctic sea ice cover during late Pleistocene glaciations is still debated, ranging

18 from a perennial sea-ice cover to that of a near kilometre thick ice shelf covering the entire basin that would essentially halt ice drift (e.g., Jakobsson et al., 2010 and publications referenced therein; Grosswald and Hughes, 2008). Recently published stratigraphic data at the Northwind Ridge close to Chukchi margin (Polyak et al., 2007) show some evidence for ice-grounding shallower than 1,000 m water depth during the Last Glacial Maximum (LGM) 23-19 thousand years before present (ka BP). Most of geophysical/geological evidence is thought to have formed in Marine Isotope Stage (MIS) 6 ( 185-132 ka BP) and was retrieved from various sites, including ice streamlines at Yermak Plateau near Fram Strait, Morris Jessup Rise north of Greenland, at the Lomonosov-Ridge close to the North Pole, Mendeleev Ridge, Northwind Ridge and Chukchi Plateau and Alaska Beaufort Margin, which do not support the idea of a shelf ice cover of Antarctic type during the LGM (Jakobsson et al., 2010). However, there are still extremes of postulated glacial sea-ice drift, varying from no substantial change from today (Phillips and Grantz, 2001) to a resting ice massif with only occasional break-up north of Fram Strait (Nørgaard-Pedersen et al., 2003; Bradley and 31 England, 2008). In the central Arctic Ocean, LGM climate reconstructions are limited and challenging due to low sedimentation rates and bioproduction (Nørgaard-Pedersen et al., 1998; Stein, 2008; Stein et al., 1994). Polyak et al. (2004) present a sedimentary record of the Mendeleev Ridge confirming that LGM sediments poorly conserve biological remains (benthic and planktonic foraminifers) favouring the interpretation of a thick lid of pack ice or even an ice-shelf covering the western Arctic Ocean. Along the continental margin at Fram Strait where modern North Atlantic waters are penetrating the Arctic Ocean. Nørgaard-Pedersen et al. (2003) suggest seasonal open water conditions and north of Fram Strait a glacial perennial ice cover. Bradley and England (2008) conclude that seasonal open water conditions along the coast from the northern edge of the Barents Sea ice-sheet to the Laptev 
(Knies et al., 1999; Vogt et al., 2001). Contrary to these findings, Müller et al. (2009) propose a permanent LGM sea-ice cover based on Biomarker data at the northern Fram Strait location (Core PS2837-5; Lat $81^{\circ} 13^{\prime} \mathrm{N}$, Long $\left.02^{\circ} 22^{\prime} \mathrm{E}\right)$.

A milestone in illuminating the LGM and providing data for numerical modeling was the first comprehensive reconstruction of global surface conditions provided by the CLIMAP (Climate: Long range Investigation, Mapping, And Prediction, 1981) project, including seasonal sea surface temperatures (SST) and extent of sea ice. CLIMAP (1981) proposed perennial ice cover in the central Arctic Ocean and Nordic Seas implying a shutdown of the northern North Atlantic inflow and seasonal sea-ice cover in the North Atlantic down to $50^{\circ} \mathrm{N}$ latitude. These findings have been revised and expanded by SST reconstructions in the Atlantic sector of the GLAMAP Group (Pflaumann et al., 2003) that show a discrepancy of $8^{\circ} \mathrm{C}$ warmer summer temperatures in the Nordic Seas. Along the Faroe-Shetland Passage, Hebbeln et al. (1994) also observed limited sea-ice expansion with seasonally open, warmer waters in the Greenland and Norwegian Seas. However, quantitative reconstructions of SST in Nordic Seas based on different proxies diverge by more than $10^{\circ} \mathrm{C}$ (de Vernal et al., 2006). They relate potential discrepancies among the proxies to diverse salinity tolerance, trophic levels, taphonomy and lateral advection. For example, $\mathrm{Mg} / \mathrm{Ca}$ ratios indicate surface temperatures up to $10^{\circ} \mathrm{C}$ (Meland et al., 2005), whereas $\delta^{18} \mathrm{O}$ values suggest less than $4^{\circ} \mathrm{C}$ both derived from shells of $N$. pachyderma assemblages at Nordic Seas (de Vernal et al., 2006). In light of the proxy uncertainties and different hypotheses of late Pleistocene glaciations in the Arctic, we address the glacial sea ice and ocean circulation by a numerical model instead. For this purpose, we deploy a regional ocean-sea ice model that has been used in recent studies (e.g., Kauker et al., 2003) and operational sea-ice cover predictions (Kauker et al., 2009), and we equip it with boundary conditions that are representative of the LGM. We use this regional ocean-sea ice model to investigate the glacial Arctic sea ice system and propose a model- and proxy-based ice drift reconstruction for the LGM. 
2. Methods and data

2.1 Experimental design

The model studies use the North Atlantic/Arctic Ocean Sea Ice Model (NAOSIM), developed at the Alfred Wegener Institute (Kauker et al., 2003; Köberle and Gerdes, 2003). The spatial domain of the ocean/sea-ice model captures the Arctic Ocean, the Nordic Seas and the northern North Atlantic $\left(90^{\circ} \mathrm{N}-50^{\circ} \mathrm{N}\right)$. The model has a horizontal resolution of $0.25^{\circ} \times 0.25^{\circ}$ per grid box $(\sim 27 \times 27 \mathrm{~km}$, respectively) and 30 unevenly spaced levels in the vertical. A dynamic-thermodynamic sea ice model with a viscous plastic rheology (Hibler, 1979) is coupled to the ocean model (Kauker et al., 2003).

\subsubsection{Atmospheric forcing}

The present model studies are forced by differing atmospheric boundary conditions including the parameters $2 \mathrm{~m}$ air temperature above surface, dew point temperature, cloudiness, precipitation, zonal and meridional component of wind speed, and surface wind stress. The modern control run (CTRL) is forced by atmospheric data fields provided by the NCEP/NCAR reanalysis project (Kalnay et al., 1996), whereas glacial atmospheric data was generated by simulations of an atmospheric boundary forcing of model study LGMC is derived from a dataset of the global atmospheric model ECHAM3/T42L19, which was adapted to the glacial boundary conditions by Lohmann and Lorenz (2000). In one sensitivity study that used sea surface temperature, ice cover as well as albedo reconstruction as per CLIMAP (1981), Lohmann and Lorenz (2000) decreased CLIMAP SSTs in the tropics $\left(30^{\circ} \mathrm{S}-30^{\circ} \mathrm{N}\right)$ by $3^{\circ} \mathrm{C}$. Compared to the standard atmospheric LGM run, the sensitivity study with artificial cooling in the tropics is in better agreement with marine and terrestrial proxy data (Lohmann and Lorenz, 2000) and is used as present atmospheric boundary forcing for LGMC. 
For another model study (LGMG), the atmospheric data fields are provided by the same atmosphere model, ECHAM3/T42L19 with glacial setup (Romanova et al., 2004). LGMG atmospheric boundary conditions are forced by glacial SST, albedo, and sea ice reconstruction of the Atlantic region provided by GLAMAP 2000 (Glacial Atlantic Ocean Mapping; Paul and Schäfer-Neth, 2003). In contrast to CLIMAP (1981), reconstructions of GLAMAP 2000 exhibit year-round warmer SSTs in North Atlantic and summer ice free conditions in the central and eastern part of the Nordic Seas with winter expansion south of Iceland and Faeroe (Pflaumann et al., 2003). The atmospheric data fields force NAOSIM twice per day and are repeated over a 15 year cycle.

\subsubsection{Glacial Arctic freshwater budget}

So far, knowledge of the glacial Arctic freshwater budget is sparse. In general the glacial circum Arctic ice sheets hindered the northward transport of latent heat (see Stein, 2008). This resulted in an isolated Arctic domain characterized by decreased temperatures and humidity and in consequence with reduced meteoric precipitation and a weakened hydrological cycle (Lohmann and Lorenz, 2000). The Pacific westerlies are split into a shifted branch southward to the flank of the Laurentide ice sheet at $40-50^{\circ} \mathrm{N}$ latitude (Clark et al., 1999; Lambeck et al., 2002) and a northward excursion across the Canadian Arctic as indicated by modeling results (e.g. Lohmann and Lorenz, 2000). The Siberian sector is influenced by cold, dry winds on the lee side of the Fenno-

Scandinavian ice sheet (Hubberten et al., 2004; Siegert and Marsiat, 2001; Siegert and Dowdeswell, 2004) as well as an anticyclonic regime over Siberia that hinders the advection of Atlantic air masses (Arkhipov et al., 1986; Velichko et al.,1997). Furthermore, the Bering Land Bridge connecting Asia and North America is blocking the Pacific inflow of freshwater for the Arctic Ocean. As a consequence the total freshwater budget for the Arctic Ocean is decreased (Martinson and Pitman, 2007). The presumed glacial Arctic river inflow roughly corresponds to half $(1,800$ $\mathrm{km}^{3} / \mathrm{a}$ ) of today's annual budget of 3,300 $\mathrm{km}^{3} / \mathrm{a}$ (Aagaard and Carmack, 1989), which ranges 
119 between glacial runoff in the $\operatorname{AGCM}\left(1,082 \mathrm{~km}^{3} / \mathrm{a}\right)$ and a modeling study using a more realistic

120 river routing $\left(\sim 2,000 \mathrm{~km}^{3} / \mathrm{a}\right.$; Alkama et al., 2008).

121 The model takes into account changes in salinity by water transport, precipitation, snowmelt, sea ice 122 melting, freezing, and river runoff. Apart from the salinity advection term in the ocean, salinity

123 fluxes in the model are not associated with momentum and volume. An additional salinity restoring

124 term at the sea surface using the present climatology of salinity fields (Levitus and Boyer, 1994;

125 Levitus et al., 1994; National Snow and Ice Data Center, 1997), prevents the model climate from

126 broadly drifting in the Arctic Ocean and is necessary to obtain a halocline (Steele et al., 2001). The

127 restoring term has a long time scale of 180 days and the additional freshwater flux adds $\sim 17 \mathrm{~mm} / \mathrm{a}$

128 to the Arctic Ocean. The salinity restoring term is applied to all model studies presented here. In

129 one sensitivity study (LGMC_sal), we applied glacial sea surface salinity from a climate model

130 output (Shin et al., 2003a, b) in order to discuss the impact on the results.

$131 \quad 2.1 .3$ Model setup

132 The control run (CTRL) uses the ocean/sea-ice model used by Kauker et al. (2003) and Köberle and

133 Gerdes (2003). The atmospheric forcing data consists of the NCEP/NCAR reanalysis project

134 (Kalnay et al., 1996) for the period 1948-2007. The last 30 years (1977-2007) of CTRL are used

135 for comparison with the glacial sensitivity studies. For the change in morphology of the glacial

136 ocean, the present-day land-sea mask (NOAA, 1988) is adapted to the ice sheets in the Northern

137 Hemisphere (Ehlers and Gibbard, 2007) and sea level is lowered by 120 m (Fairbanks, 1989).

138 Thermodynamic processes on a sub-grid scale, like open water areas between sea-ice, seven ice

139 classes are defined following a Gaussian distribution around the mean sea-ice thickness. Model

140 studies without limitations show sea-ice thickness $>80 \mathrm{~m}$ after 120 modeled years along the

141 northern Barents Sea shelf edge, north of Greenland and Baffin Bay without reaching an

142 equilibrated sea-ice thickness. In the glacial model runs, the potential mean sea-ice thickness of

143 each grid cell is limited to a maximum of $30 \mathrm{~m}$ in order to reach equilibrium. The upper limit of

144 mean sea-ice thickness in the sea-ice model was motivated by the maximum height of pressure 
145 ridges observed by present-day observations of first-year ice as reported by Polyak et al. (2010). As

146 a consequence of the glacial water storage over land, an additional increase in salinity of 1 psu

147 (practical salinity unit) is prescribed for the open boundary condition of the northern North Atlantic

148 inflow. In order to account for a temperature decrease, the lateral temperature at the southern

149 boundary is reduced by $2^{\circ} \mathrm{C}$, consistent with global ocean simulations (e.g., Butzin et al., 2005).

150 Experiments testing the prescribed southern boundary characteristics (barotropic stream function)

151 with a glacial model setup have only minor effects on the through flow of the Arctic Ocean (cf. Fig.

152 S8).

153 The ocean model is initialized by an LGM simulation of a general circulation model (NCAR-

154 CCSM; Shin et al., 2003a, b) and the initial conditions of the sea-ice model (zonal and meridional

155 component of sea-ice drift velocities, snow-cover thickness, sea-ice thickness) are set to zero to

156 avoid any preconditioning.

157 We note that the total water mass of the upper Arctic Ocean layer $(0-1,000 \mathrm{~m})$ of the NAOSIM

158 present-day setup is typically exchanged within 30 years (Karcher and Oberhuber, 2002) in

159 agreement with observations on tracer contaminants (MacDonald and Bewers 1996; MacDonald et

160 al. 2004). The lengths of the model runs are 120 model years, only the last 30 years are used for

161 analysis. Major contribution of present water mass exchange happens through western Fram Strait,

162 where salty and warm Atlantic waters enter the Arctic Ocean in the upper $200 \mathrm{~m}$ (Fig. S7a). All of

163 our glacial model simulations exhibit a displaced inflow of bottom waters $>2 \mathrm{~m} / \mathrm{s}$ stronger than the

164 Atlantic Water Current in CTRL, which equals an increase of surface outflow of the Arctic Ocean

165 because of mass conservation (Fig. S7b-f, Fig. S8). Changes in the barotropic stream function

$166( \pm 50 \%$ psi compared to LGMC) at the southern boundary of the prescribed northern North Atlantic

167 inflow as already shown for present-day conditions (Kauker et al., 2005) don't significantly impact

168 rates of water exchange at Fram Strait (Fig. S8). In response experiments with present-day setup

169 Kauker et al. (2005) state that barotropic anomalies at $50^{\circ} \mathrm{N}$ latitude do not pass the Greenland-

170 Scotland Ridge, but an increase of $2^{\circ} \mathrm{C}$ for the upper $500 \mathrm{~m}$ of the southern boundary water column 
171 effectively warms the West Spitsbergen Current by $\sim 0.5^{\circ} \mathrm{C}$ (as shown in $300 \mathrm{~m}$ depth) within two 172 years.

173 In order to analyze the importance of glacial wind fields with respect to the respective SST

174 reconstruction and the presence of glacial ice sheets, we performed another sensitivity study. The 175 sensitivity study (LGMC_PDw, LGMG_PDw) uses the glacial setup (LGMC, LGMG) and is run 176 with present-day wind fields (Lohmann and Lorenz, 2000).

\subsection{Geological data}

178

The sedimentary record shown in Fig. 1 is derived from AMS $^{14}$ C-dated box core PS1230 (Lat $78^{\circ} 51^{\prime} \mathrm{N}$, Long $04^{\circ} 46^{\prime} \mathrm{W}$; 1,235 m below sea level; Darby et al., 2002; Darby and Zimmerman, 2008), which is located at the centre of modern sea-ice export through Fram Strait (Vinje et al., 1998). Using a geochemical fingerprinting method, Darby et al. (2002) and Darby and Zimmerman (2008) are able to identify the source of individual detrital iron oxide minerals (in the $45-250 \mu \mathrm{m}$ fraction) transported by sea ice and/or icebergs. Geographically distinct sources of sea-ice formation and/or iceberg calving are identified by $>2000$ circum-Arctic compositional groups applying statistical analysis (clustering and discriminant function analysis; Darby et al., 2002). The statistical approach typically matches $50-60 \%$ of the analyzed grains per sample ( 100 grains), therefore a weighted percentage (wt\%) is used to avoid anomalously large percentages when grain numbers are low (Zimmerman and Darby, 2008). In general, the sedimentary record shows an elevated level of coarse IRD during late MIS3 ( 60-27 ka BP) and MIS2 ( 27-12 ka BP) including the LGM (Fig.1, marked in blue), whereas the Holocene signal (12-0ka) is dominated by finegrained sediment $(<10 \%$ coarse fraction; marked in red). The fine-grained nature of this Holocene sediment suggests sea-ice rafted debris (Pfirman et al., 1989; Reimnitz et al., 1998; Nürnberg et al., 1994; Darby et al., 2011). For the reconstruction of glacial/interglacial ice-drift pattern (Fig. 1, solid blue and dashed red lines) the same method was applied to a transect of sediment cores bisecting the central Arctic Ocean (Bischof and Darby, 1997). 
Furthermore geophysical evidence of the sea-floor along the Alaska-Beaufort margin (Engels et al., 2008) and Chukchi-Borderland (Polyak et al., 2001; 2007) show glaciogenic iceberg scours, which indicate grounding of large ice masses and the direction of ice drift that are used for model comparison (Fig. 1).

\section{Results}

3.1 Simulation of Arctic sea-ice dynamics and thermodynamics

For CTRL, mean westerlies are $>4.5 \mathrm{~m} / \mathrm{s}$ in the northern North Atlantic sector and katabatic winds are localized above the Greenland ice sheet (Fig. 2). The Nordic Seas of LGMC are enclosed by katabatic winds off the eastern flank of Greenland ice sheet and the western flank of the Barents Sea ice sheet, whereas the speed of westerlies is reduced compared to CTRL. The wind speeds in LGMG compared to LGMC are larger in general and form an anomalous Icelandic Low (Fig. 2c). In the central Arctic Ocean, a closed perennial sea-ice cover with mean thickness of $3 \mathrm{~m}$ is found (Fig. 4a). Perennial ice, $>8 \mathrm{~m}$ thick, is observed primarily in parts of the northern coast of the Canadian Archipelago and the coast of northern Greenland (Fig. 4a). The sea-ice drift follows the Beaufort Gyre and Transpolar Drift (Fig. 5a) exiting the Arctic Ocean through Fram Strait. Today's single year sea-ice, represented by present day control run (CTRL), evolves and melts in the circum 213 Arctic shelf-seas and further south especially in Baffin Bay and along the East Greenland Current 214 within a year (Fig. 3a,d). The minimum of modern sea-ice export across Fram Strait is directly 215 linked to the minimum sea-ice extent in late summer (Fig. 3, Fig. 6) with a dramatic drop of sea-ice velocities starting in May $(9.4 \mathrm{~cm} / \mathrm{s})$ and reaching its minimum in September $(2.3 \mathrm{~cm} / \mathrm{s})$ before recovering (Fig. S5). Present locations of sea-ice formation include the entire circum-Arctic

218 shelves, especially the expansive, shallow marine shelf areas of the Laptev, Kara and East Siberian 219 Seas (not shown). In contrast, the central glacial Arctic Ocean in LGMG and LGMC is almost completely isolated 221 from the atmosphere by a perennial sea-ice cover throughout the year (Fig. 3). Only in the Beaufort 
222 Sea, along the shelf edge of the Canadian Archipelago is sea ice produced within open water areas 223 (polynyas) (Fig. 3). The northern branch of Pacific westerlies, which are split by the Laurentide ice224 sheet is directed towards the Beaufort Sea and Canadian Archipelago (Fig. 2). There, early stage sea ice is pushed offshore into the Beaufort Sea and open water surfaces are conserved along the coast (Fig. 3; Fig. 4). At the northern Barents, Kara, and Laptev Sea shelf edge enclosing the Eurasian Basin, sea ice is stuck $(<0.2 \mathrm{~cm} / \mathrm{s}$ sea-ice drift) along the rim and reaches the upper limit of prescribed ice thickness (Fig. 4 b. c). Further north of the rim and along the Siberian shelf edge August sea-ice cover declines to $<50 \%$ in LGMG and $<60 \%$ in LGMC (Fig. 3 b, c). This is mainly caused by ice dynamics, since surface air temperatures during summer rarely reach positive values and surface ocean waters are close to the freezing point (not shown).

A general zonal gradient of sea-ice thickness in the Nordic Seas (Fig. 4) is maintained by two flow 234 Spitsbergen Current in addition to katabatic winds offshore of the Barents Sea ice sheet (Fig. 2) 235 limit sea-ice cover there (Fig. 4). The southward East Greenland Current (EGC) carries cold, relatively fresh water and sea ice from the Arctic. Along the EGC, a permanent sea-ice cover arises and extends to the oceanic polar front, which separates polar and Arctic water masses (Fig. 3). In contrast, seasonal sea-ice production occurs in the Arctic and Atlantic waters of the Nordic Seas. In 239 LGMG less sea-ice concentration than LGMC with seasonally open water conditions along a more pronounced North Atlantic inflow is shown in the Nordic Seas (Fig. 3b, e; Fig. 4b). Baffin Bay is characterized by a permanent, static sea-ice cover and sea-ice thickness close to the artificial limit of $30 \mathrm{~m}$ (Fig. 3; Fig. 4b, c). In the southern region of Baffin Bay, the sea-ice cover destabilizes (Fig. $4 \mathrm{~b}, \mathrm{c})$, and inter-annual ice-free areas emerge at the West Greenland coast of the Labrador Sea, where sea ice is formed again. The juvenile sea ice in the Beaufort Sea moves anti-cyclonally across the Canadian Basin and merges with a transpolar drift towards Fram Strait (Fig. 5b, c). In the glacial scenarios, the gyre of sea-ice drift is centered in the Amerasian Basin further towards the Ellesmere Island compared to CTRL. Generally the colder glacial climate scenario based on CLIMAP data 
shows a slow linear stream flow pattern directly towards Fram Strait. North of Ellesmere Island glacial sea ice either gets entrapped in the anticyclonic gyre (LGMG) or takes a direct pathway along the coast of Greenland to Fram Strait (LGMC). In contrast to present-day sea-ice export, the Laptev-Sea and Kara-Sea shelf edge barely show offshore transport of ice. Along the Barents and Kara Sea shelf edge, sea-ice drift is comparably faster in LGMG than in LGMC (Fig. 5b, c).

3.2 Water mass characteristics at Fram Strait and in the central Arctic Ocean

The sea-ice drift in the glacial Arctic Basin is a result of a balance between wind stress and ocean drag (and internal ice stress). In order to understand the contribution of ocean drag, it is necessary to analyse the vertical structure of water masses. For present day (CTRL) the mean sea surface salinity fields of the central Arctic domain are $\sim 31 \mathrm{psu}$ and $\sim 33 \mathrm{psu}$ for LGMG and LGMC, respectively (see supplementary Fig. S1a, b, c). The halocline in the central Arctic Ocean is situated at $\sim 200 \mathrm{~m}$ for

260 CTRL and $\sim 80 \mathrm{~m}$ for the glacial sensitivity studies and a barotropic mode prevails (LGMG, LGMC, 261 Fig. S1d, e, f). All presented glacial simulations show enhanced Arctic inflow of Atlantic bottom waters (ca. $-3.5 \mathrm{~m} / \mathrm{s})$, colder $\left(<-1.8^{\circ} \mathrm{C}\right)$ and saltier $(>36 \mathrm{psu})$ than present day, and the outflow of fresh Arctic waters at the water surface. At the present location of the West Spitsbergen Current glacial model studies exhibit a similar to present day maximum speed $(\sim 1 \mathrm{~m} / \mathrm{s})$ of waters entering the Arctic. Along the East Greenland Current the outflow is centered at around $200 \mathrm{~m}$ water depth through Fram Strait. Since the present-day Atlantic water inflow is shifted towards the bottom, an Arctic boundary current west of Svalbard exhale through Fram Strait (Fig. S7b-f, Fig. S8). The boundary current is consistent with the general ocean circulation in the central Arctic Ocean of the glacial model scenarios (not shown). For the glacial model studies the water passage through the Barents Sea is blocked by an ice sheet which potentially redirects a branch of the North Atlantic

271 Current towards Fram Strait leading to increased water mass exchange at this location. Modulations of the Atlantic water stream function at the southern boundary of the model do not affect water properties at Fram Strait (Fig. S8). A similar effect has been reported by Kauker et al. (2005) for 
present-day conditions. We note that deeper levels of the ocean model are not in full equilibrium (see supplement). Based on LGMC we set up a sensitivity study for the surface salinity restoring term using surface salinity fields derived from the NCAR-CCSM output (Shin et al., 2003a, b). For the glacial Arctic Ocean the surface salinity anomaly of the new restoring term is higher than LGMC, but the overall large-scale effect is almost additive (Fig. S2a). The absence of relative fresh Pacific waters in the Beaufort Sea is mimicked by the surface salinity restoring term with maximum surface salinity anomalies of $\sim 4$ psu (Fig. S2a). An increase of salinity in the Arctic surface waters (Fig. S2a) deepens the halocline as indicated at the Fram Strait section (Fig. S7d). The exchange of water masses at Fram Strait is decreased and similar in pattern compared to other glacial model studies, but still higher than present-day. Higher surface salinity can also impact the formation of sea ice and the quantity of sea-ice transport through Fram Strait but does not affect the overall results presented in this study (Fig. S2b, c).

\subsection{Arctic sea-ice thickness and its export to Nordic and Labrador Seas}

Along the transport path in the direction of Fram Strait, sea ice (mostly driven by dynamical ice growth) increases its thickness between 11 and $20 \mathrm{~m}$ (Fig. 4b, c). At this location, temperature and wind stress of the respective model run (LGMC, LGMG) as well as ice resistance, determine the velocity of the ice drift and the sea-ice thickness. As ice drift rates in LGMC are by up to $2 \mathrm{~cm} / \mathrm{s}$ lower than in LGMG (Fig. 5b, c, Fig. S5), the residence time of Arctic sea ice is prolonged, and up to $20 \mathrm{~m}$ ice thickness evolves just north of Fram Strait (Fig. 4c). The simulated sea-ice export rate through Fram Strait $\left((95 \pm 21) \times 10^{3} \mathrm{~m}^{3} / \mathrm{s}\right.$; Table 1) in CTRL is consistent with estimates based on observation values of a 50-yr period (1950-2000: 91.9 $\pm 21.1 \times 10^{3} \mathrm{~m}^{3} / \mathrm{s}$; Vinje, 2001). The minimum of present-day sea-ice transport during late summer (Fig. 6) is associated with a dramatic decline in summer ice-drift velocities (Fig. S5). Also present-day sea-ice thickness across Fram Strait decreases in September and recovers during winter months (Fig. S6). Seasonal sea-ice export in CTRL is dominated by changes in ice drift velocities $(2.3-10.8 \mathrm{~cm} / \mathrm{s}$, Fig. S5). The sea ice melts along the East Greenland Current and rarely reaches the Denmark Strait $\left((30 \pm 10) \times 10^{3} \mathrm{~m}^{3} / \mathrm{s}\right.$ of sea- 
ice export). However up to three times more sea-ice quantity exiting through Fram Strait in the

301 glacial model runs LGMG and LGMC (Table 1) is transported into the Nordic Seas (Fig. 6). The

302 elevated glacial sea-ice flux into the Nordic Seas is caused by thicker sea ice exiting the Fram Strait

303 (Fig. S6). During summer the glacial ice cover destabilizes north of Fram Strait and thick sea ice, up

304 to $10.5 \mathrm{~m}$ in LGMC and $8.5 \mathrm{~m}$ in LGMG, is crossing the gateway (Fig. S6), causing maximum sea-

305 ice export in September (Fig. 6). During the rest of the year glacial sea-ice export is predominantly

306 influenced by variation of ice drift velocity (Fig. S5). The ice drifts via the East Greenland Current

307 southwards into the ablation areas of the Labrador Sea and into the region south of Iceland (Fig. 5b,

308 c). Here, it becomes apparent that the sea-ice export through the Denmark Strait (LGMG: (348 \pm 17$)$

$309 \times 10^{3} \mathrm{~m}^{3} / \mathrm{s}$; LGMC: $(163 \pm 30) \times 10^{3} \mathrm{~m}^{3} / \mathrm{s}$; Table 1$)$ reacts to changes in wind fields. Additional sea

310 ice, formed in the Nordic Seas, is transported in LGMG via the Denmark Strait in the direction of

311 the Labrador Sea. This is due to enhanced cyclonic circulation over Iceland (Fig. 2c).

312 In LGMC_PDw and LGMG_PDw, the ocean model is forced with present-day wind fields: Sea-ice 313 export through Fram Strait is significantly reduced (Fig. S3), the gradient of sea-ice thickness (Fig.

314 S4a, b), and local areas of sea-ice formation in the Arctic Ocean change. Without katabatic winds

315 off the Barents-Sea ice sheet and stronger westerlies than during LGM (Fig. 2) the zonal gradient of

316 sea-ice cover is not simulated (Fig. S4a, b). From late summer until late spring (August until

317 March) the southward transport of sea-ice through Faroe-Shetland Passage and across Iceland-Faroe 318 Ridge is reversed (not shown). Therefore the standard deviation, shown in Table 1 exceeds the 319 mean of sea-ice export through both gateways.

\section{Discussion}

4.1 Model performance under glacial conditions

323 The ice strength parameter, formulating rheology of sea-ice models, is tuned to fit present-day

324 observational values. It describes the softness/hardness of sea ice relevant for deformation processes 325 and build-up of pressure ridges and is typically adapted to the time step of the atmospheric forcing. 
The actual ice thickness is directly affected by this parameter and exhibits a linear relationship to ice strength. For sea-ice thicknesses $>3 \mathrm{~m}$, where sea-ice growth is primarily driven by ridging and rafting, the ice strength might be underestimated (non-linear) leading to anomalous high pressure ridges like shown in the present-day simulation at CAA and northern Greenland (Fig. 4a). The compressive strength of sea ice sheets increases as the ice thickens due to the fact that thick sea ice is generally less saline as shown by material measurements (Timco and Frederking, 1990). But still, material properties of old multiyear sea ice are poorly observed (Timco and Weeks, 2010).

333 Consequently the glacial model simulations would suggest a rather extreme case of sea-ice 334 thickness in the central Arctic Ocean. For elaborating the effect of ice strength parameterization sensitivity studies of varying ice strength parameter values could be setup and a regime shift in case of extreme ice thicknesses might be implemented in the model. Since these problems are beyond the scope of our work, follow-up studies of the glacial Arctic marine cryosphere and tuning of the 338 present-day model configuration can focus on these questions.

339 It should be noted, that our model approach lacks potential atmosphere-ocean feedbacks (Bengtsson 340 et al., 2004; Semenov et al., 2009), especially in the hydrological cycle and Bering Strait through 341 flow by the restoring term (see section 2.1.2). The freshwater budget and surface runoff affecting 342 the stratification in the Arctic Ocean during LGM remains unclear and has to be defined in more 343 detail, since our studies suggest that stratification is dominated by salinity.

344 Jakobsson et al. (2010) test the freshwater balance of a conceptual two-layer model of the Arctic 345 Ocean. A decrease in freshwater supply of the upper Arctic halocline layer (as expected by a 346 decrease in the hydrological cycle of a cold climate, see section 2.1.2) results in an increase of 347 Atlantic water influx through Fram Strait (Jakobsson et al., 2010). However, interpreted 348 neodymium isotope data from the ACEX sediment core location, Lomonosov Ridge, suggest a 349 longer residence time of bottom water masses during glacial intervals (Haley et al., 2008). Here we 350 reconcile glacial water mass exchange through Fram Strait by a three dimensional ocean simulation. 351 The glacial model scenarios show a consistent, stronger than present-day water mass exchange 
across Fram Strait (Fig. S7). Modifications of the Arctic freshwater balance and thus surface halocline waters do not effectively change the through flow of Fram Strait waters (Fig. S7) favoring inflow of North Atlantic waters as an operator. Experiments testing the prescribed southern boundary barotropic stream function with a glacial model setup have only minor affects on the Arctic Ocean (Fig. S8). However, Kauker et al. (2005) have shown that changes in the baroclinicity of southern boundary characteristics of the model with a present-day setup can progress into the Arctic within two years. Indeed model-data comparison actually favor a shoaling and weakening of the glacial Atlantic Meridional Overturning Circulation (Hesse et al., 2011, and references therein), which suggests stronger baroclinicity in the North Atlantic sector.

Earlier experiments with NAOSIM show a strong effect of continental freshwater and Pacific water through Bering Strait on the Arctic circulation (Prange and Lohmann, 2003; Lohmann et al., 2005). For the early Holocene, the model studies suggest that a gradual increase in the flux of Pacific water through Bering Strait slowly affects the polar climate by melting ice, increasing stratification, and causing an enhanced anticyclonic pattern over the Canadian Basin and the East Siberian Sea (Lohmann et al., 2005; Dyck et al., 2010). As a logical next step, we will elaborate the effect of Arctic freshwater on the Arctic circulation during the termination of the LGM. 4.2 Atmospheric circulation of the glacial Nordic Seas.

Our results are also interesting for the validation of paleoclimate reconstructions. In the Nordic Seas, the prescribed atmospheric boundary conditions are not consistent with the simulated sea-ice cover. Neither a perennial ice cover proposed by CLIMAP (1981) nor a seasonal ice cover (GLAMAP; Pflaumann et al., 2003) is captured by our studies, indicating a general mismatch of ocean/sea-ice dynamics and SST-reconstruction. This emphasizes the importance of ice sheets and SST reconstruction in the Atlantic sector modifying the atmospheric circulation (Byrkjedal et al., 2006) and therefore sea-ice cover.

The annual mean sea-ice export from the Arctic (0.19-0.26 Sv) continues south via the EGC and is modified by sea ice melting along the way, being deflected or reinforced by seasonal ice, which 
mainly evolved in the Norwegian Sea (not shown). Due to zonal drift patterns, a gradient of sea-ice thickness becomes apparent in the Nordic Seas (Fig. 4b,c). Meland et al. (2005) also find the pattern of that gradient in their SST reconstruction. In the absence of katabatic winds off the Barents-Sea ice sheet, the zonal pattern cannot be obtained (Fig. S4). Byrkjedal et al. (2006) have shown that the presence of sea-ice in the northern North Atlantic sector diminishes the Icelandic Low in contrast to less sea ice in the northern North Atlantic Ocean which favors the formation of a cyclonic pattern. In turn LGMG suggests that a moderate cyclonic circulation over Iceland contributes to enhanced sea-ice export across Denmark-Strait. The sea-ice transport from the Arctic Ocean and the Nordic Sea across the Denmark Strait (0.16-0.32 Sv) contributes to the freshwater budget in the northern North Atlantic.

4.3 Hypotheses of the glacial marine cryosphere in the central Arctic Ocean

The solid lines shown in Fig. 1 indicate the glacial ice drift proposed by Bischof and Darby (1997), compared to the recent patterns (dashed lines). Present sea-ice formation and sediment entrainment take place primarily in shallow water $(<50 \mathrm{~m}$ water depth) of the Siberian Shelf. The Laptev Sea and the Kara Sea are important regions for sediment-laden sea ice along today`s Transpolar Drift (Nürnberg et al., 1994). This signal is reflected for the last $8 \mathrm{ka}$ in the fine-grained sediment composition, an indicator for sea-ice rafted debris (Pfirman et al., 1989; Reimnitz et al., 1998; Nürnberg et al., 1994). The provenance of Fram Strait sediment was determined by matching the chemical signature of detrital iron oxide grains to $>2000$ potential circum-Arctic source compositions (Darby et al., 2002; Darby and Zimmerman, 2008). The sediments of the last ice age in the Fram Strait sediment core PS1230 are primarily from the Canadian Arctic Archipelago (Banks Island, Queen Elizabeth Island), which was covered by the Laurentide and Innuitian ice sheets at that time (Ehlers and Gibbard, 2007). Calving Laurentide ice into the Arctic Ocean at this time occurred along the Amundsen Trough (Stokes et al., 2006) and the M'Clure Strait (Stokes et 
al., 2005). It has not yet been clarified whether these calving events led to an ice shelf in the Arctic

405 Ocean or whether perennial sea ice with icebergs of Antarctic dimension prevailed (Jakobsson et 406 al., 2010). The Eurasian shelf seas were either covered by the Fennoscandinavian ice sheet (Ehlers and Gibbard, 2007) or exposed.

408 We propose that icebergs, which are also an important transport medium for sediments especially 409 during the transition from glacial maxima to deglacial intervals, moved in the Arctic Ocean 410 synchronously with sea ice. While the iceberg drift is usually directed by several forces (water drag, 411 wind stress, Coriolis force, inclination of the sea surface and interaction with sea-ice cover), iceberg 412 drift buoys in the Weddell Sea (Antarctic) confirm that there is a coherent sea ice/iceberg 413 movement at $\sim 90 \%$ sea-ice concentration (Schodlok et al., 2006). Low sedimentation rates, the 414 absence of microorganisms, or even a hiatus in the sediment record, actually imply a thicker than 415 today perennial ice cover with little melting in the central Arctic Ocean (Nørgaard-Pedersen et al., 416 1998; Polyak et al., 2004; Stein et al., 1994; Stein, 2008). The model studies show a gradient of sea417 ice thickness across the Arctic Ocean that is different from today. Due to the convergence of drift, 418 sea ice is compressed to thicknesses of 11-20 m just north of Greenland and the advection area of 419 Fram Strait, comparable to the recent pressure ridges of up to 20-30 m thickness in this area (e.g., 420 Polyak et al., 2010). Whereas halted sea-ice would accumulate snowfall which slowly converts 421 snow to firn and glacier ice up to $40 \mathrm{~m}$ height as seen from landfast-ice remnants of the little ice-age 422 (Bradley and England, 2008). In this case variations of ice thickness in the central Arctic Ocean 423 would be dependent on the surface mass balance and thermodynamic processes. Bradley and 424 England (2008) argue that limited atmospheric circulation in the glacial Arctic Ocean favor this 425 process and propose a mean ice thickness of $50 \mathrm{~m}$ in the Arctic Ocean. In the atmospheric forcing 426 of our model studies, the North Pacific westerlies at the Laurentide ice sheet diverge forming a 427 southern and northern branch. Winds of the northern branch are redirected across CAA intruding to the Arctic interior where sea-ice along the coast of CAA is pushed offshore to the central Arctic 
Ocean. Sea ice is converging and pressure ridges of exceptional height evolve along its way towards

430 Fram Strait forming a trans-arctic gradient of sea-ice thickness controlled by sea-ice dynamics.

431 4.4 Comparison of simulated and reconstructed glacial ice drift

432 Pleistocene ice drift reconstruction is illustrated by Phillips and Grantz (2001) utilizing the average 433 MIS2 composition and distribution of erratics in Arctic Ocean sediments. They propose that the 434 main Arctic circulation patterns, the Beaufort Gyre and Transpolar Drift operated, on average, 435 during late Pleistocene glacial episodes. Further they associate westward migration of eolian sand 436 dunes across northern Alaska (e.g. Dinter et al., 1990) with wind patterns driving the Beaufort Gyre 437 at least since the LGM. In general these findings agree with the applied wind forcing fields of our 438 model studies (Fig. 2b, c) as well as the anticyclonic sea-ice rotation in the Amerasian Basin (Fig. $4395 b, c)$.

440 Furthermore, ice plough marks (Fig. 1, blue arrows) along the Alaskan Beaufort Sea shelf edge and 441 the border area of the Chukchi Sea, dated to the LGM, imply the orientation of ice drift (Engels et al., 2008; Polyak et al., 2001; Polyak et al., 2007), which is consistent with the clockwise circulation in our model studies (Fig. 5b,c). Based on the IRD and DFA analysis Bischof and Darby (1997) reconstruct iceberg trajectories originating from northwest Canada and the western Canadian Arctic Archipelago (Amundson Trough) traversing the Northwind Ridge and Chukchi Plateau 446 before reaching Fram Strait. Icebergs sourcing from the Queen Elizabeth Islands primarily take a 447 more direct route across central and southeastern Alpha Ridge (Bischof and Darby, 1997). They 448 state that icebergs from the Innuitian and Laurentide ice-sheet take a direct pathway out of the 449 Arctic Ocean without multiple anticyclonic rotations in the Amerasian Basin (Fig. 1, blue lines). In 450 our glacial model studies we still observe a downscaled anticyclonic gyre of ice drift in the Western 451 Arctic whose center of rotation is shifted towards CAA compared to the present-day. This actually 452 allows ice of the northern edge of the Laurentide ice-sheet to traverse the central Arctic Ocean in an 453 arched pattern along the western Arctic shelf margin without multiple rotation in the glacial gyre 454 (Fig. 5b,c) as proposed by Bischof and Darby (1997). During at least two glacial maxima, 
diamicton was deposited by grounding ice at the Chukchi Borderland (Polyak et al., 2007), which would divert sea-ice drift further northwards. Ice at the rim of the Innuitian ice sheet either takes the same arched pattern (LGMG, Fig. 5b) or slowly moves parallel to the coast of northern Greenland towards Fram Strait (LGMC, Fig. 5c). Differences in the atmospheric circulation (Fig. 2c) and pressure fields in the Arctic cause deviations in size and location of the anticyclonic ice drift pattern of LGMC and LGMG (Fig. 5). Further the reduced speed of sea-ice drift of our glacial model studies is directly affected by increased internal ice stress due to elevated ice thickness (not shown). Between Ellesmere Island and North Greenland (Lincoln Sea) Larsen et al. (2010) mapped glacial landforms and sediments and found evidence of shelf-based ice during the early stages of the last glacial $\sim 30 \mathrm{ka}$ ago, which is not in the scope of the ocean/sea-ice model. For the formation of an ice shelf, thick multiyear sea-ice is required in order to disable shelf-ice calving into the ocean (Jakobsson et al., 2010; Larsen et al., 2010). The initialization started with outlet glacier streams that were deflected by the eastward sea-ice movement and final coalescence into an ice-shelf (Larsen et al., 2010). In our model studies, the Lincoln Sea is occupied by perennial sea-ice of maximum thickness (Fig. 4b, c) and virtually no ice-drift (Fig. 5b, c), which are favorable conditions for sustaining an ice-shelf. Further north, multi-year ice is drifting at $0.2-1 \mathrm{~cm} / \mathrm{s}$ eastwards in agreement with the scenario of Larsen et al. (2010).

\section{$\underline{\text { 5. Conclusions }}$}

The panarctic ice-shelf cover postulated by Grosswald and Hughes (2008) provides an extreme case of glaciation with virtually no ice drift, which is not supported by our model simulations as well as more recent reconstructions (Jakobsson et al., 2010) nor the IRD record in Fram Strait (Darby and Zimmerman, 2008). Phillips and Grantz (2001) point out that the Beaufort Gyre and Transpolar Drift have been stable during late Pleistocene forced by wind fields consistent with proxy evidence from North Alaska. In contrast, our model studies still show an anti-cyclonic rotation in the Canadian Basin, which is shifted compared to the present-day pattern and a Transpolar Drift which 
481 is deflected or not present during LGM. Applying modern wind fields to the glacial model setup 482 result in a general mismatch of simulated ice drift, ice cover and proxy data. As a consequence 483 glacial wind stress is interpreted as the dominant operator of sea-ice drift. The arched pattern of 484 simulated sea-ice drift results in a gradient of sea-ice thickness in the Arctic Ocean that is 485 predominantly forced by glacial wind fields. The sources of MIS2 IRD in Fram Strait and other 486 parts of the Arctic (Darby et al., 2002; Darby and Zimmerman, 2008) and the orientation of dated 487 ice plough marks (Engels et al., 2008; Polyak et al., 2001; Polyak et al., 2007) substantiate our 488 results.

489 Our approach overcomes the drawbacks of global climate models in representing circulation 490 changes on a regional scale. The validation of our high-resolution regional Arctic ocean-sea ice 491 model, which has been used for hindcast and sea-ice prediction so far (Kauker et al., 2009) against 492 the Last Glacial Maximum is crucial to understand physical processes concerning other climate 493 regimes than today.

495 Acknowledgments

496 We thank the AWI sea ice group for model support and Axel Wagner for technical assistance. Part 497 of the work was funded by the German Science Foundation (DFG) within the research unit UCCC 498 and the Alfred Wegener Institute through the program PACES in collaboration with the 499 Biodiversity and Climate Research Centre BiK-F established in the LOEWE framework. Part of this 500 paper is based on a diploma thesis conducted at the Alfred Wegener Institute in cooperation with 501 Technische Universität Bergakademie Freiberg. 
1. Aagaard, K., Carmack, E.C., 1989. The Role of Sea Ice and Other Fresh Water in the Arctic Circulation. J. Geophys. Res. (C10), 14485-14498.

2. Alkama, R., Kageyama, M., Ramstein, G., Marti, O., Ribstein, P., Swingedouw, D., 2008. Impact of a realistic river routing in coupled ocean-atmosphere simulations of the Last

3. Arkhipov, S.A., Isayeva, L.L., Bespaly, V.G., Glushkova, O., 1986. Glaciation of Siberia and north-east USSR. Quaternary Science Reviews (0), 463-474.

4. Bengtsson, L., Semenov, V.A., Johannessen, O.M., 2004. The Early Twentieth-Century Warming in the Arctic-A Possible Mechanism. J. Climate (20), 4045-4057.

5. Bischof, J.F., Darby, D.A., 1997. Mid- to Late Pleistocene Ice Drift in the Western Arctic Ocean: Evidence for a Different Circulation in the Past. Science (5322), 74-78.

6. Bradley, R.S., England, J.H., 2008. The Younger Dryas and the Sea of Ancient Ice. Quaternary Res. (1), 1-10.

7. Butzin, M., Prange, M., Lohmann, G., 2005. Radiocarbon simulations for the glacial ocean: The effects of wind stress, Southern Ocean sea ice and Heinrich events. Earth Planet. Sci. Lett. (1-2), 45-61.

8. Byrkjedal, Ø., Kvamstø, N., Meland, M., Jansen, E., 2006. Sensitivity of last glacial maximum climate to sea ice conditions in the Nordic Seas. Clim. Dynam. (5), 473-487.

9. Clark, P.U., Alley, R.B., Pollard, D., 1999. Northern Hemisphere Ice-Sheet Influences on Global Climate Change. Science (5442), 1104-1111.

10. CLIMAP, 1981. Seasonal Reconstruction of the Earth's Surface at the Last Glacial Maximum. Geological Society of America Map and Chart Series MC-36.

11. Darby, D.A., Bischof, J.F., Spielhagen, R.F., Marshall, S.A., Herman, S.W., 2002. Arctic ice export events and their potential impact on global climate during the late Pleistocene. Paleoceanography (2). 
12. Darby, D.A., Zimmerman, P., 2008. Ice-rafted detritus events in the Arctic during the last glacial interval, and the timing of the Innuitian and Laurentide ice sheet calving events. Polar Res. (2), 114-127.

13. Darby, D.A., W.B. Myers, M. Jakobsson, and I. Rigor, 2011. Modern dirty sea ice doi:10.1029/2010JC006675.

14. Dinter, D.A., Carter, L.D., Brigham-Grette, J., 1990. Late Cenozoic geologic evolution of the Alaskan North Slope and adjacent continental shelves. In: Grantz, A., Johnson, G.L., Sweeney, J.F. (Eds.), The Arctic Ocean region. The Geology of North America. Boulder, Colorado, Geological Society of America, 459-490.

15. Dyck, S., Tremblay, L.B., de Vernal, A., 2010. Arctic sea-ice cover from the early Holocene: the role of atmospheric circulation patterns. Quaternary Sci. Rev. (25-26), 34573467.

16. Ehlers, J., Gibbard, P.L., 2007. The extent and chronology of Cenozoic Global Glaciation. Quaternary Int., 6-20.

17. Engels, J.L., Edwards, M.H., Polyak, L., Johnson, P.D., 2008. Seafloor evidence for ice shelf flow across the Alaska-Beaufort margin of the Arctic Ocean. Earth Surface Processes and Landforms (7), 1047-1063.

18. Fairbanks, R.G., 1989. A 17,000-year glacio-eustatic sea level record: influence of glacial melting rates on the Younger Dryas event and deep-ocean circulation. Nature (6250), 637642.

19. Grosswald, M., Hughes, T., 2008. The case for an ice shelf in the pleistocene Arctic Ocean. Polar Geogr. (1), 69-98.

20. Haley, B.A., Frank, M., Spielhagen, R.F., Fietzke, J., 2008. Radiogenic isotope record of Arctic Ocean circulation and weathering inputs of the past 15 million years. Paleoceanography (1), PA1S13. 
21. Hebbeln, D., Dokken, T., Andersen, E.S., Hald, M., Elverhøi, A., 1994. Moisture supply for northern ice-sheet growth during the Last Glacial Maximum. Nature (6488), 357-360.

22. Hesse, T., Butzin, M., Bickert, T., Lohmann, G., 2011. A model-data comparison of $\delta 13 \mathrm{C}$ in the glacial Atlantic Ocean. Paleoceanography (3), PA3220.

23. Hibler, W.D., 1979. A Dynamic Thermodynamic Sea Ice Model. J. Phys. Oceanogr. (4), 815-846.

24. Hubberten, H.W., Andreev, A., Astakhov, V.I., Demidov, I., Dowdeswell, J.A., Henriksen, Lyså, A., Mangerud, J., Möller, P., Saarnisto, M., Schirrmeister, L., Sher, A.V., Siegert, C., Siegert, M.J., Svendsen, J.I., 2004. The periglacial climate and environment in northern Eurasia during the Last Glaciation. Quaternary Sci. Rev. (11-13), 1333-1357.

25. Jakobsson, M., Nilsson, J., O'Regan, M., Backman, J., Löwemark, L., Dowdeswell, J.A., Mayer, L., Polyak, L., Colleoni, F., Anderson, L.G., Björk, G., Darby, D., Eriksson, B., Hanslik, D., Hell, B., Marcussen, C., Sellén, E., Wallin, Å., 2010. An Arctic Ocean ice shelf during MIS 6 constrained by new geophysical and geological data. Quaternary Sci. Rev. (25-26), 3505-3517.

26. Kalnay, E., Kanamitsu, M., Kistler, R., Collins, W., Deaven, D., Gandin, L., Iredell, M., Saha, S., White, G., Woollen, J., Zhu, Y., Leetmaa, A., Reynolds, R., Chelliah, M., Ebisuzaki, W., Higgins, W., Janowiak, J., Mo, K.C., Ropelewski, C., Wang, J., Jenne, R., Joseph, D., 1996. The NCEP/NCAR 40-Year Reanalysis Project. Bull. Am. Meteorol. Soc. (3), 437-471.

27. Karcher, M.J., Oberhuber, J.M., 2002. Pathways and modification of the upper and intermediate waters of the Arctic Ocean. J. Geophys. Res. (C6).

28. Kauker, F., Kaminski, T., Karcher, M., Giering, R., Gerdes, R., Voßbeck, M., 2009. Adjoint analysis of the 2007 all time Arctic sea-ice minimum. Geophys. Res. Lett. (3), L03707. 
29. Kauker, F., Gerdes, R., Karcher, M., Köberle, C., 2005. Impact of North Atlantic Current changes on the Nordic Seas and the Arctic Ocean. J. Geophys. Res (C12), C12002.

30. Kauker, F., Gerdes, R., Karcher, M., Köberle, C., Lieser, J.L., 2003. Variability of Arctic and North Atlantic sea ice: A combined analysis of model results and observations from 1978 to 2001. J. Geophys. Res. (C6).

31. Knies, J., Nowaczyk, N., Müller, C., Vogt, C., Stein, R., 2000. A multiproxy approach to reconstruct the environmental changes along the Eurasian continental margin over the last 150000 years. Mar. Geol. (1-4), 317-344.

32. Köberle, C., Gerdes, R., 2003. Mechanisms Determining the Variability of Arctic Sea Ice Conditions and Export. J. Clim. (17), 2843-2858.

33. Lambeck, K., Esat, T.M., Potter, E.-K., 2002. Links between climate and sea levels for the past three million years. Nature (6903), 199-206.

34. Larsen, N.K., Kjær, K.H., Funder, S., Möller, P., van der Meer, J.J.M., Schomacker, A., Linge, H., Darby, D.A., 2010. Late Quaternary glaciation history of northernmost Greenland - Evidence of shelf-based ice. Quaternary Sci. Rev. (25-26), 3399-3414.

35. Levitus, S., Boyer, T.P., 1994. Temperature. NOAA Atlas NESDIS 4. U.S. Department of Commerce. Washington, D.C.

36. Levitus, S. et al., 1994. Salinity. NOAA Atlas NESDIS 4. U.S. Department of Commerce. Washington, D.C.

37. Lohmann, G., Lorenz, S., 2000. On the hydrological cycle under paleoclimatic conditions as derived from AGCM simulations. J. Geophys. Res. (D13), 17417-17436.

38. Lohmann, G., Lorenz, S.J., Prange, M., 2005. Northern high-latitude climate changes during the Holocene as simulated by circulation models, In: Drange, H., Dokken, H., Furevik, T., Gerdes, R., Berger, W. (eds.), The Nordic Seas: An Integrated Perspective, Geophysical Monograph 158, American Geophysical Union, Washington, DC, pp. 273-288. doi:10.1029/158GM18. 
39. Macdonald, R.W., Bewers, J.M., 1996. Contaminants in the arctic marine environment: priorities for protection. ICES Journal of Marine Science: Journal du Conseil (3), 537-563. 40. MacDonald R.W. et al., (2004). The Arctic Ocean: modern status and recent climate change. In: Stein, R., MacDonald, R.W. (eds.), The organic carbon cycle in the Arctic Ocean. Springer, Heidelberg, 6-21.

41. Martinson, D., Pitman, W., 2007. The Arctic as a trigger for glacial terminations. Climatic Change, 253-263.

42. Meland, M.Y., Jansen, E., Elderfield, H., 2005. Constraints on SST estimates for the northern North Atlantic/Nordic Seas during the LGM. Quaternary Sci. Rev. (7-9), 835-852.

43. Müller, J., Massé, G., Stein, R., Belt, S.T., 2009. Variability of sea-ice conditions in the Fram Strait over the past 30,000 years. Nature Geosci. (11), 772-776.

44. National Snow and Ice Data Center (NSIDC). 1997. Joint U.S. Russian Atlas of the Arctic Ocean, Oceanography Atlas for the Winter Period. Boulder.

45. NOAA, 1988. Data Announcement 88-MGG-02, Digital relief of the Surface of the Earth. National Geophysical Data Center. Boulder, Colorado.

46. Nørgaard-Pedersen, N., Spielhagen, R.F., Erlenkeuser, H., Grootes, P.M., Heinemeier, J., Knies, J., 2003. Arctic Ocean during the Last Glacial Maximum: Atlantic and polar domains of surface water mass distribution and ice cover. Paleoceanography (3), 1063.

47. Nørgaard-Pedersen, N., Spielhagen, R.F., Thiede, J., Kassens, H., 1998. Central Arctic Surface Ocean Environment During the Past 80,000 Years. Paleoceanography (2), 193-204. 48. Nürnberg, D., Wollenburg, I., Dethleff, D., Eicken, H., Kassens, H., Letzig, T., Reimnitz, E., Thiede, J., 1994. Sediments in Arctic sea ice: Implications for entrainment, transport and release. Mar. Geol. (3-4), 185-214.

49. Otto-Bliesner, B.L., Hewitt, C.D., Marchitto, T.M., Brady, E., Abe-Ouchi, A., Crucifix, M., Murakami, S., Weber, S.L., 2007. Last Glacial Maximum ocean thermohaline circulation: PMIP2 model intercomparisons and data constraints. Geophys. Res. Lett. (12), L12706. 
50. Paul, A., Schäfer-Neth, C., 2003. Modeling the water masses of the Atlantic Ocean at the Last Glacial Maximum. Paleoceanography (3), 1058.

51. Pfirman, S., Gascard, J.-C., Wollenburg, I., Mudie, P., Abelmann, A., 1989. Particle-laden Eurasian Arctic sea ice: observations from July and August 1987. Polar Res. (1), 59-66.

52. Pflaumann, U., Sarnthein, M., Chapman, M., d'Abreu, L., Funnell, B., Huels, M., Kiefer, T., Maslin, M., Schulz, H., Swallow, J., van Kreveld, S., Vautravers, M., Vogelsang, E., Weinelt, M., 2003. Glacial North Atlantic: Sea-surface conditions reconstructed by GLAMAP 2000. Paleoceanography (3), 1065.

53. Phillips, R.L., Grantz, A., 2001. Regional variations in provenance and abundance of ice640 oceanic and atmospheric circulation in the Arctic. Mar. Geol. (1-2), 91-115.

54. Polyak, L., Alley, R.B., Andrews, J.T., Brigham-Grette, J., Cronin, T.M., Darby, D.A., Dyke, A.S., Fitzpatrick, J.J., Funder, S., Holland, M., Jennings, A.E., Miller, G.H., O'Regan, M., Savelle, J., Serreze, M., St. John, K., White, J.W.C., Wolff, E., 2010. History of sea ice in the Arctic. Quaternary Sci. Rev. (15-16), 1757-1778.

55. Polyak, L., Darby, D.A., Bischof, J.F., Jakobsson, M., 2007. Stratigraphic constraints on late Pleistocene glacial erosion and deglaciation of the Chukchi margin, Arctic Ocean. Quaternary Res. (2), 234-245.

56. Polyak, L., Curry, W.B., Darby, D.A., Bischof, J., Cronin, T.M., 2004. Contrasting glacial/interglacial regimes in the western Arctic Ocean as exemplified by a sedimentary record from the Mendeleev Ridge. Palaeogeography, Palaeoclimatology, Palaeoecology (12), 73-93.

57. Polyak, L., Edwards, M.H., Coakley, B.J., Jakobsson, M., 2001. Ice shelves in the Pleistocene Arctic Ocean inferred from glaciogenic deep-sea bedforms. Nature (6827), 453457. 
58. Prange, M., Lohmann, G., 2003. Effects of mid-Holocene river runoff on the Arctic oceansea ice system: a numerical study.Holocene 13 (3), 335-342.

59. Reimnitz, E., McCormick, M., Bischof, J., Darby, D.A., 1998. Comparing sea-ice sediment 659 load with Beaufort Sea shelf deposits; is entrainment selective? Journal of Sedimentary Research (5), 777-787.

61. Romanova, V., Prange, M., Lohmann, G., 2004. Stability of the glacial thermohaline circulation and its dependence on the background hydrological cycle. Clim. Dynam., 527538.

62. Schodlok, M.P., Hellmer, H.H., Rohardt, G., Fahrbach, E., 2006. Weddell Sea iceberg drift: Five years of observations. J. Geophys. Res. (C6).

63. Semenov, V.A., Park, W., Latif, M., 2009. Barents Sea inflow shutdown: A new mechanism for rapid climate changes. Geophys. Res. Lett (14), L14709.

64. Shin, S.-I., Liu, Z., Otto-Bliesner, B., Brady, E., Kutzbach, J., Harrison, S., 2003a. A Simulation of the Last Glacial Maximum climate using the NCAR-CCSM. Clim. Dynam. (20), 127-151.

65. Shin, S.-I., Liu, Z., Otto-Bliesner, B.L., Kutzbach, J.E., Vavrus, S.J., 2003b. Southern Ocean sea-ice control of the glacial North Atlantic thermohaline circulation. Geophys. Res. Lett. (2), 1096.

66. Siegert, M.J., Dowdeswell, J.A., 2004. Numerical reconstructions of the Eurasian Ice Sheet and climate during the Late Weichselian. Quaternary Sci. Rev. (11-13), 1273-1283.

67. Siegert, M.J., Marsiat, I., 2001. Numerical reconstructions of LGM climate across the Eurasian Arctic. Quaternary Sci. Rev. (15), 1595-1605. 
68. Steele, M., Ermold, W., Häkkinen, S., Holland, D., Holloway, G., Karcher, M., Kauker, F., Maslowski, W., Steiner, N., Zhang, J., 2001. Adrift in the Beaufort Gyre: A model intercomparison. Geophys. Res. Lett. (15), 2935-2938.

69. Stein, R., 2008. Arctic ocean sediments. Developments in Marine Geology, 2. Elsevier, Amsterdam. 592 pp.

70. Stein, R., Schubert, C., Vogt, C., Fütterer, D., 1994b. Stable isotope stratigraphy, sedimentation rates, and salinity changes in the Latest Pleistocene to Holocene eastern central Arctic Ocean. Mar. Geol. (3-4), 333-355.

71. Stokes, C.R., Clark, C.D., Winsborrow, M.C.M., 2006. Subglacial bedform evidence for a major palaeo-ice stream and its retreat phases in Amundsen Gulf, Canadian Arctic Archipelago. J. Quaternary. Sci. (4), 399-412.

72. Stokes, C.R., Clark, C.D., Darby, D.A., Hodgson, D.A., 2005. Late Pleistocene ice export events into the Arctic Ocean from the M'Clure Strait Ice Stream, Canadian Arctic Archipelago. Global Planet. Change (3-4), 139-162.

73. Svendsen, J.I., Alexanderson, H., Astakhov, V.I., Demidov, I., Dowdeswell, J.A., Funder, S., Gataullin, V., Henriksen, M., Hjort, C., Houmark-Nielsen, M., Hubberten, H.W., Ingólfsson, Ó., Jakobsson, M., Kjær, K.H., Larsen, E., Lokrantz, H., Lunkka, J.P., Lyså, A., Mangerud, J., Matiouchkov, A., Murray, A., Möller, P., Niessen, F., Nikolskaya, O., Polyak, L., Saarnisto, M., Siegert, C., Siegert, M.J., Spielhagen, R.F.; Stein, R., 2004. Late Quaternary ice sheet history of northern Eurasia. Quaternary Sci. Rev. (11-13), 1229-1271. 74. Timco, G.W., Frederking, R.M.W., 1990. Compressive strength of sea ice sheets. Cold Regions Sci. Tech. (3), 227-240.

75. Timco, G.W., Weeks, W.F., 2010. A review of the engineering properties of sea ice. Cold Regions Sci. Tech. (2), 107-129.

76. Velichko, A.A., Kononov, Y.M., Faustova, M.A., 1997. The last glaciation of earth: Size and volume of ice-sheets. Quaternary Int. (0), 43-51. 
706 77. de Vernal, A., Rosell-Melé, A., Kucera, M., Hillaire-Marcel, C., Eynaud, F., Weinelt, M., 707 Dokken, T., Kageyama, M., 2006. Comparing proxies for the reconstruction of LGM seasurface conditions in the northern North Atlantic. Quaternary Sci. Rev. (21-22), 2820-2834.

709 78. Vinje, T., 2001. Fram Strait Ice Fluxes and Atmospheric Circulation: 1950-2000. J. Clim. $710 \quad$ (16), 3508-3517.

711 79. Vogt, C., Knies, J., Spielhagen, R.F., Stein, R., 2001. Detailed mineralogical evidence for 712 two nearly identical glacial/deglacial cycles and Atlantic water advection to the Arctic 713 Ocean during the last 90,000 years. Global Planet. Change (1-4), 23-44. 


\section{$\underline{\text { Figure Captions }}$}

Fig. 1: Reconstruction of last glacial/interglacial ice drift in the Arctic Ocean. Black land/sea-mask marks the modern and grey, the glacial boundaries of the model. Weighted proportion (wt\%) of the iron oxide grains from core PS1230 (Lat $78^{\circ} 51^{\prime} \mathrm{N}$, Long $04^{\circ} 46^{\prime} \mathrm{W} ; 1,235 \mathrm{~m}$ water depth) (Darby et al., 2002;Darby and Zimmerman, 2008), assigned to the individual regions of origin (blue and red areas). Solid blue lines indicate glacial, dashed red lines are interglacial ice drift (Bischof and Darby, 1997). Blue arrows indicate ice plough marks, dated to the LGM (Engels et al., 2008; Polyak et al., 2001; Polyak et al., 2007).

Fig. 2: Atmospheric boundary forcing of wind fields $10 \mathrm{~m}$ above surface $(\mathrm{m} / \mathrm{s})$ for the respective model studies. (a): 30-year mean (years 1977-2007) of wind fields derived from NCAR/NCEP reanalysis data (Kalnay et al., 1996) to force present-day model run (CTRL). (b): 15-year mean of wind field data referring to the cold glacial exeriment LGMC. (c): Anomaly plot of 15-year mean of wind field forcing data LGMG-LGMC.

Fig. 3: Mean sea-ice concentration (100\%) for summer (August) in the upper row and winter (February) conditions in the lower row are displayed. (a), (d): Present-day control run CTRL. (b), (e): LGMG. (c), (f): LGMC.

Fig. 4: Mean sea-ice thickness (m) for modern and glacial conditions. (a): Present-day control run (CTRL). (b): LGMG. (c): LGMC.

Fig. 5: Streamlines of 30-yr mean sea-ice drift ( $\mathrm{cm} / \mathrm{s})$ for modern and glacial conditions. (a): Model study CTRL. (b): LGMG. (c): LGMC. Not shown: sea ice drift with a mean sea ice concentration of 
$<10 \%$ (in general northern North Atlantic; see Fig. 3) and a velocity of $<0.2 \mathrm{~cm} / \mathrm{s}$ (e.g. Canadian Archipelago, Baffin Bay).

Fig. 6: Seasonal cycle of mean sea-ice export $\left(\mathrm{Sv}=10^{6} \mathrm{~m}^{3} / \mathrm{s}\right)$ across the Fram Strait for CTRL, LGMG and LGMC.

Table 1: Mean sea-ice transport and standard deviation $\left(10^{3} \mathrm{~m}^{3} / \mathrm{s}\right)$ through ocean gates of the North Polar Seas and budget of the Nordic Seas are shown for each model study. Positive (negative) values denote sea-ice import (export) to Nordic Seas.

\begin{tabular}{|l|l|l|l|l|l|}
\hline & Fram Strait & Denmark & Iceland-Faroe & Faroe- & $\Delta$ Nordic Seas \\
& & Strait & Ridge & Shetland & sea-ice \\
& & & & Passage & transport \\
\hline CTRL & $95 \pm 21$ & $-30 \pm 10$ & 0 & 0 & 65 \\
\hline LGMG & $264 \pm 32$ & $-348 \pm 17$ & $-60 \pm 14$ & $-3 \pm 2$ & -147 \\
\hline LGMC & $194 \pm 40$ & $-163 \pm 30$ & $-139 \pm 26$ & $-8 \pm 9$ & -116 \\
\hline LGMG_PDw & $115 \pm 38$ & $-153 \pm 41$ & $-1 \pm 25$ & $6 \pm 6$ & -33 \\
\hline LGMC_PDw & $88 \pm 33$ & $-146 \pm 39$ & $-1 \pm 51$ & $27 \pm 36$ & -32 \\
\hline
\end{tabular}




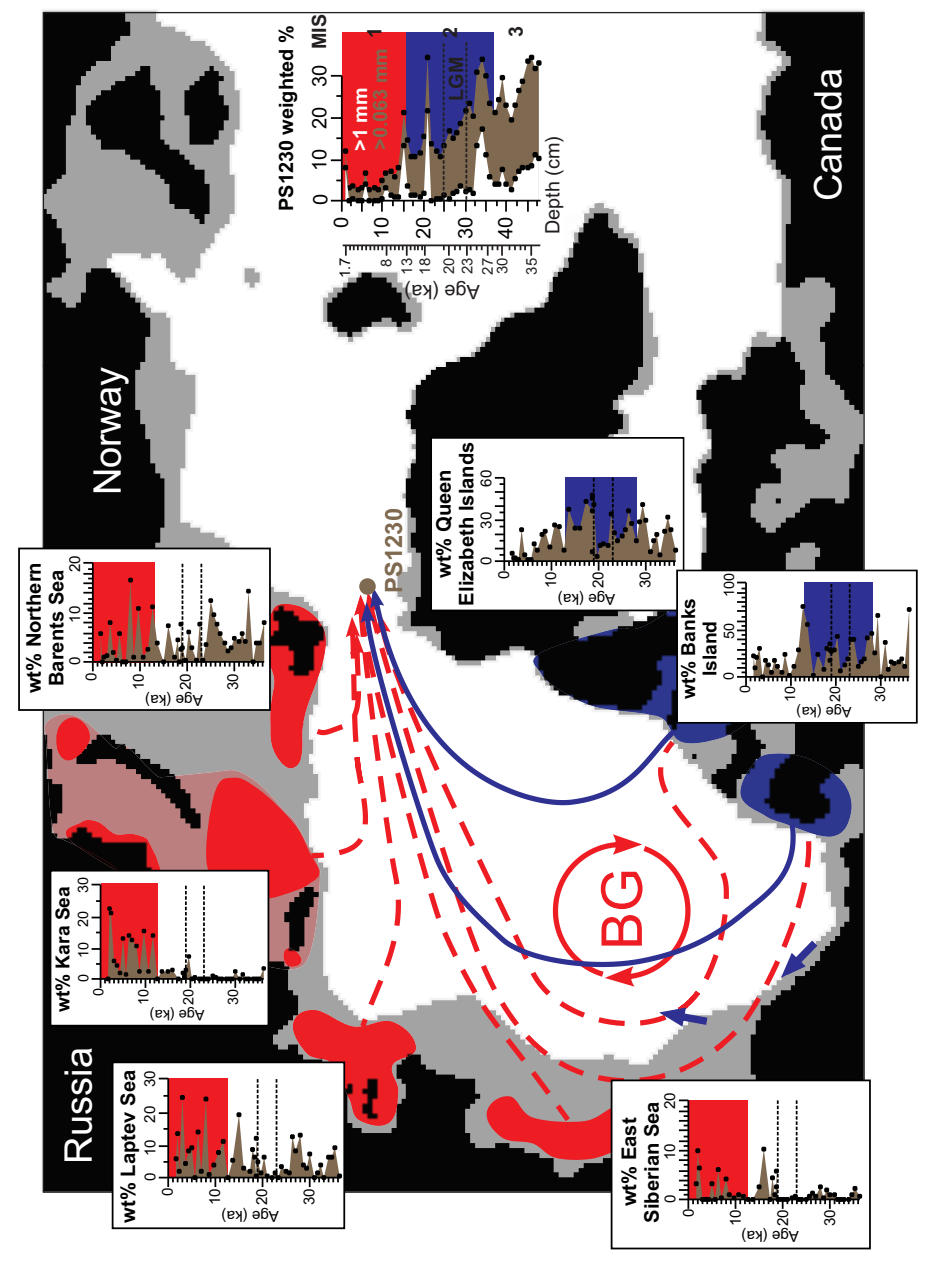



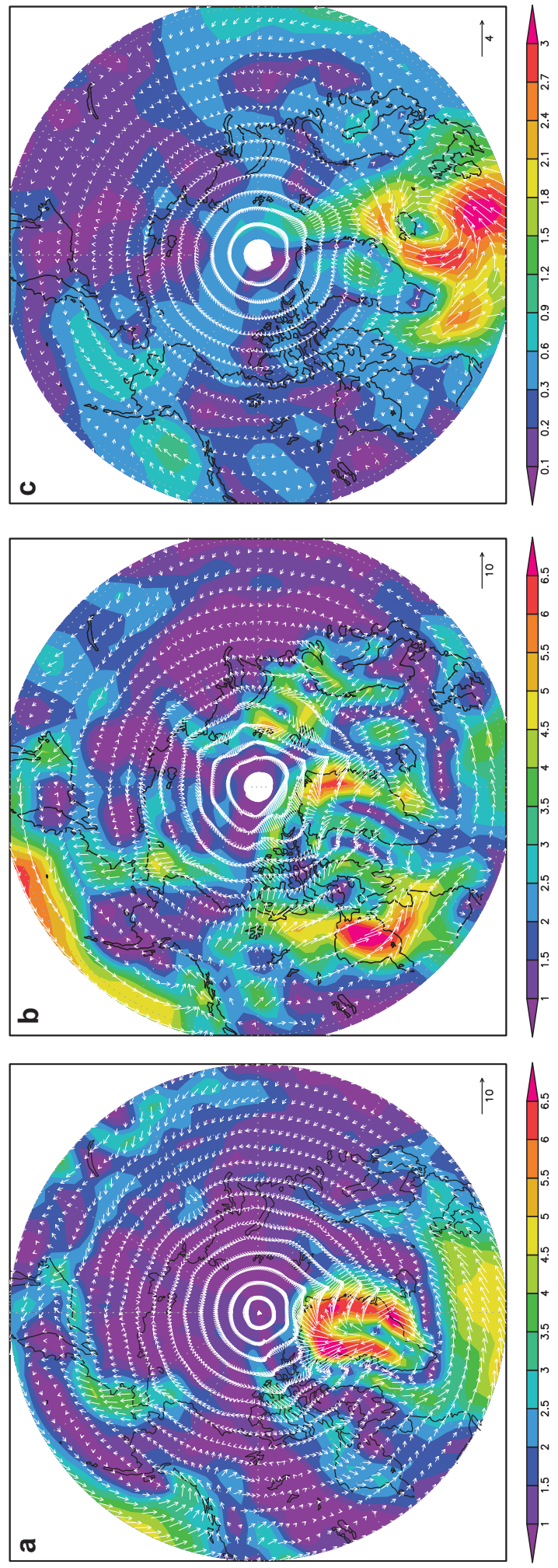

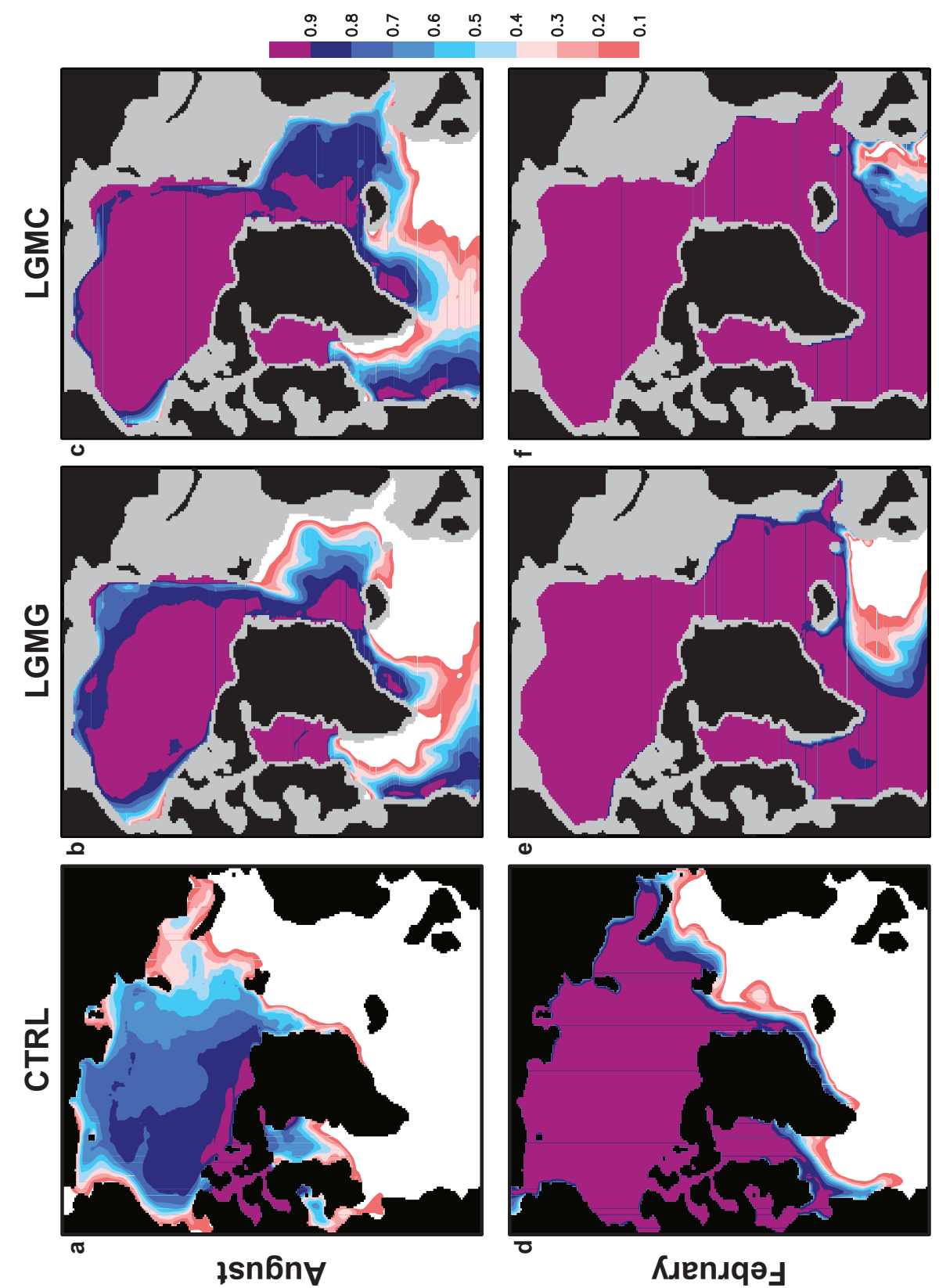


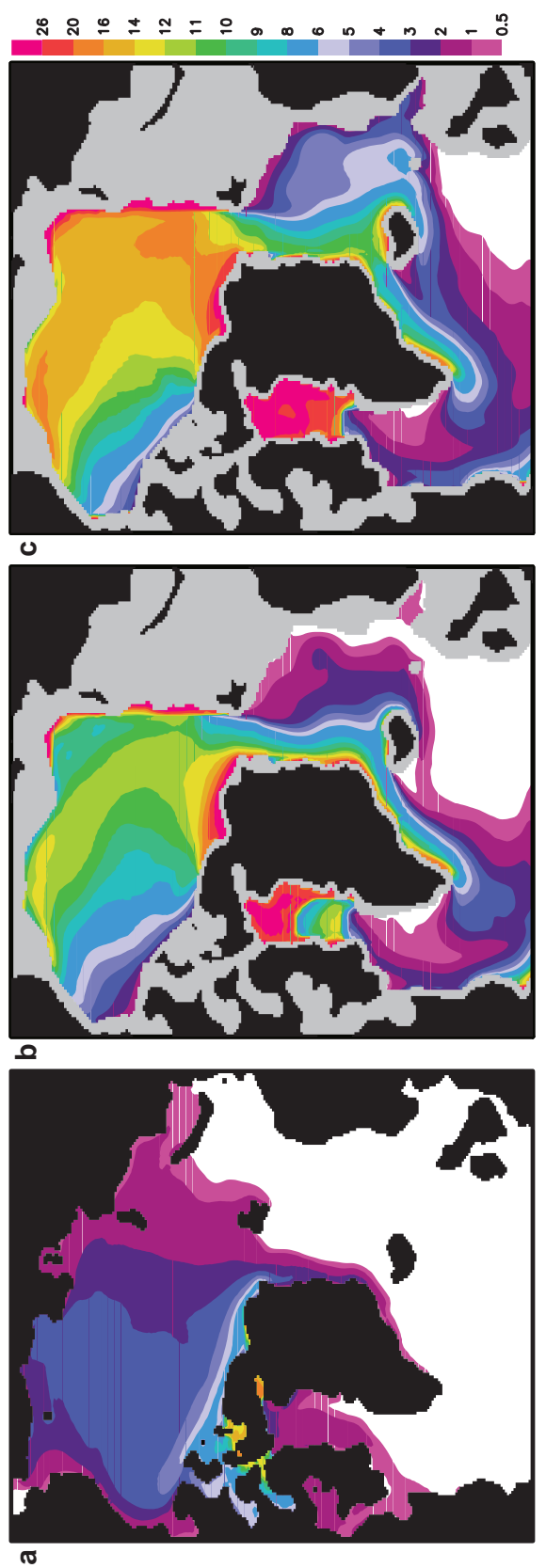




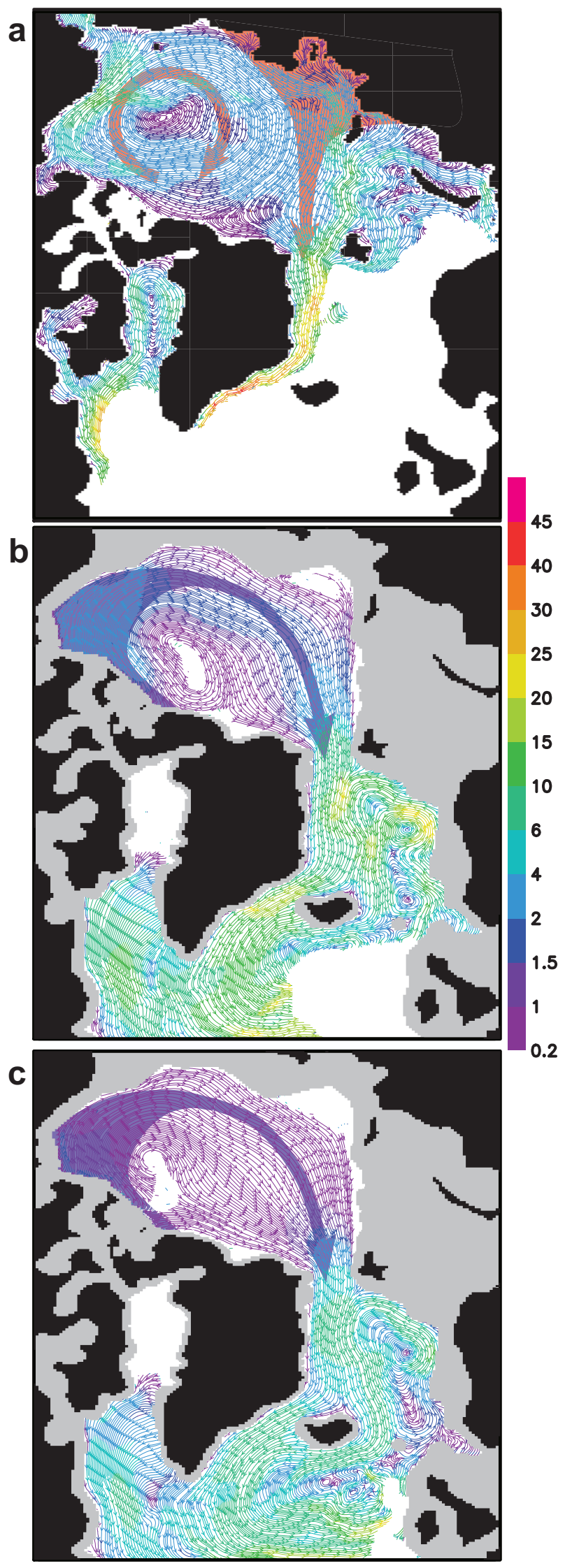




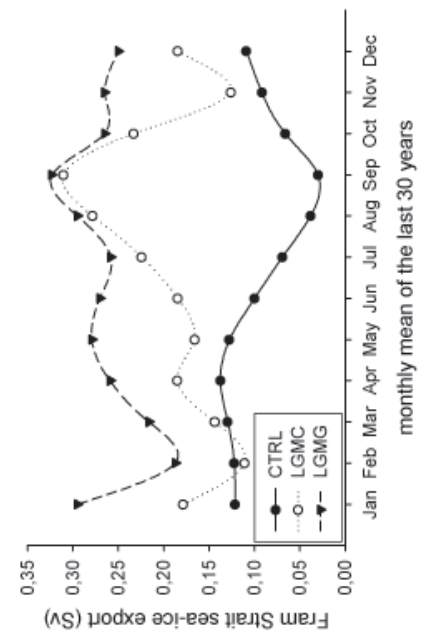




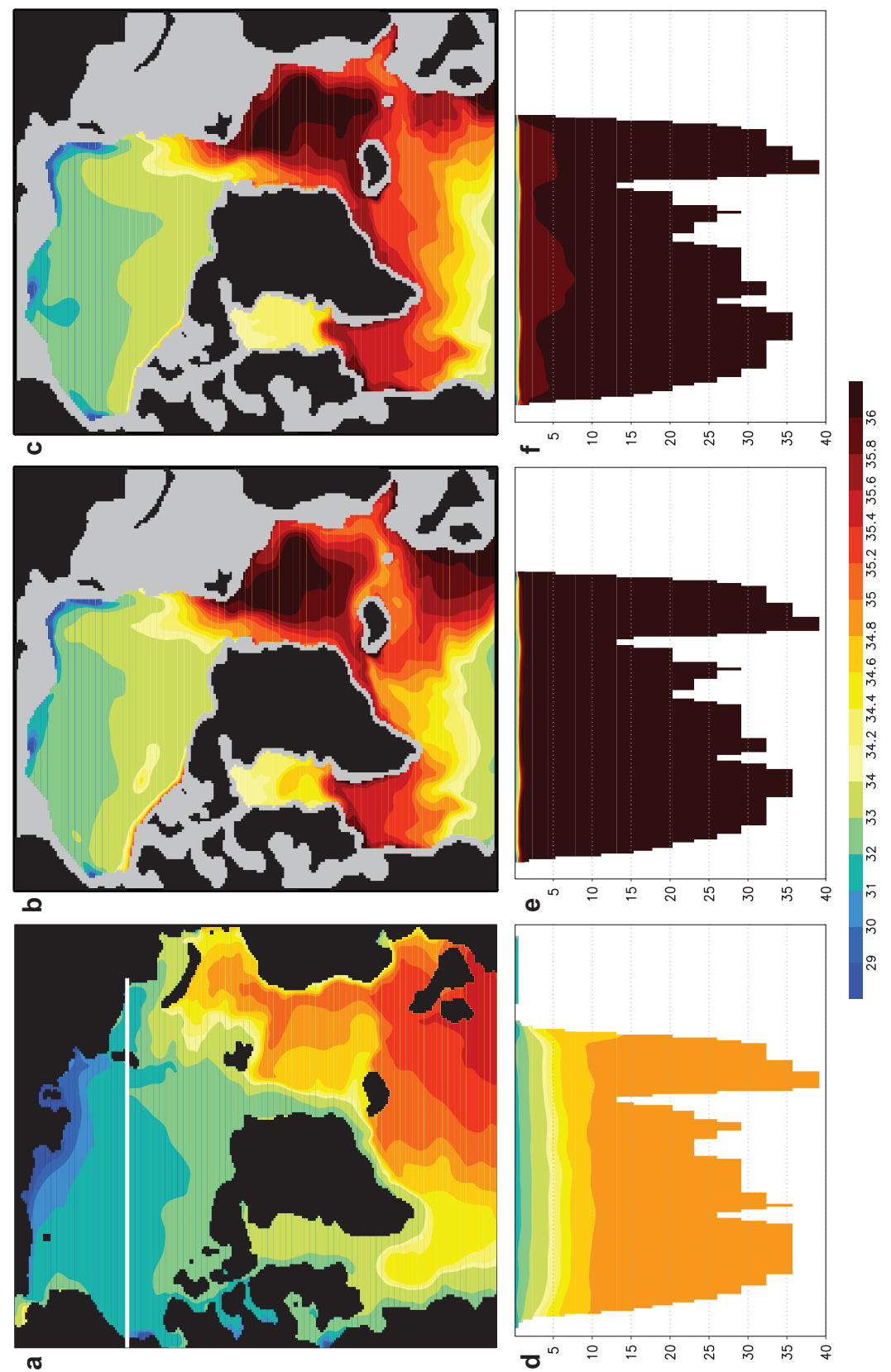




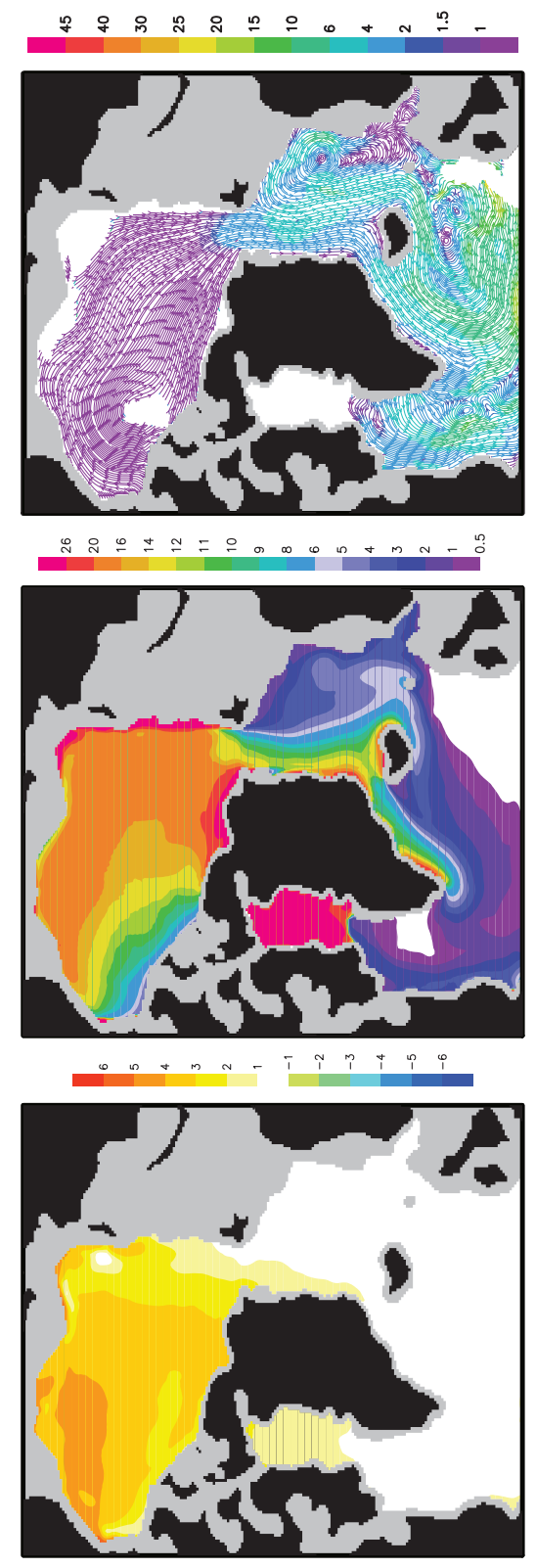




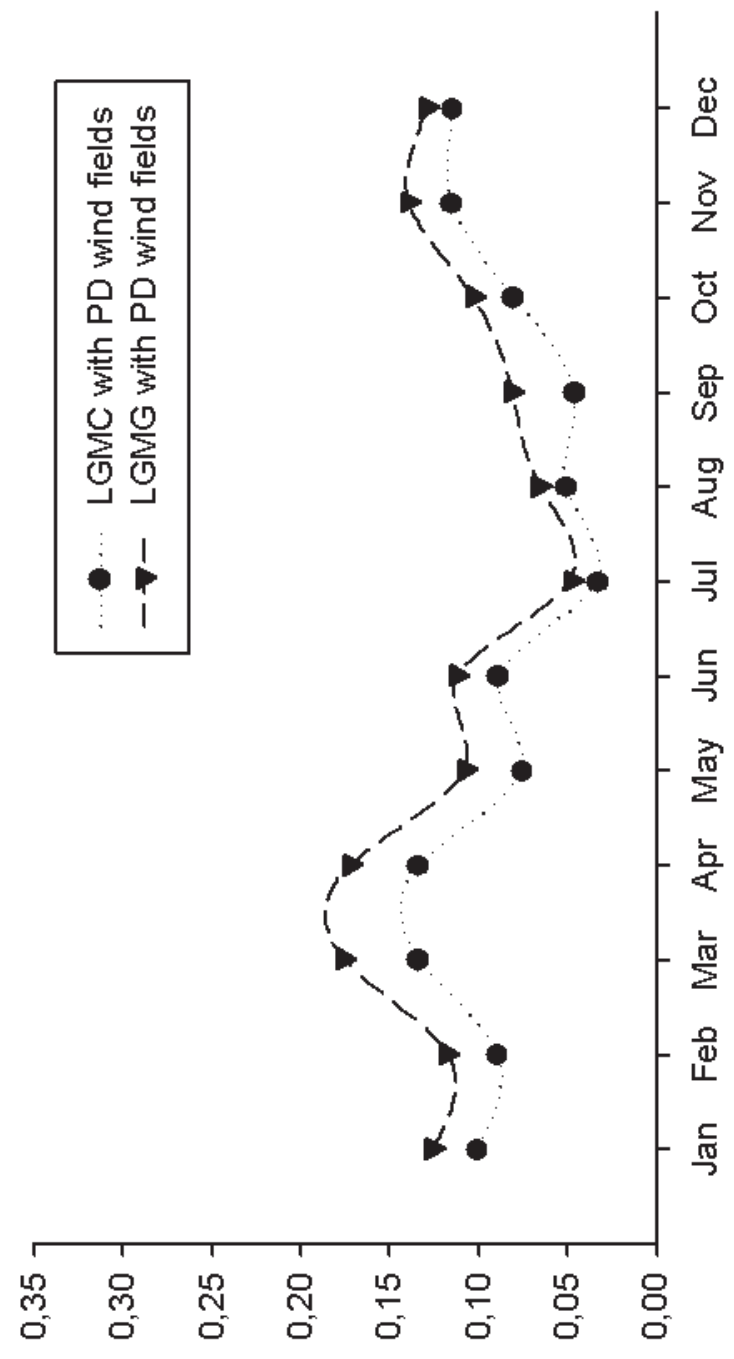

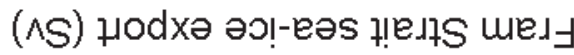




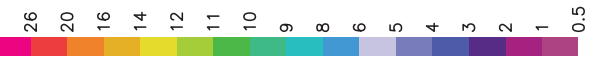
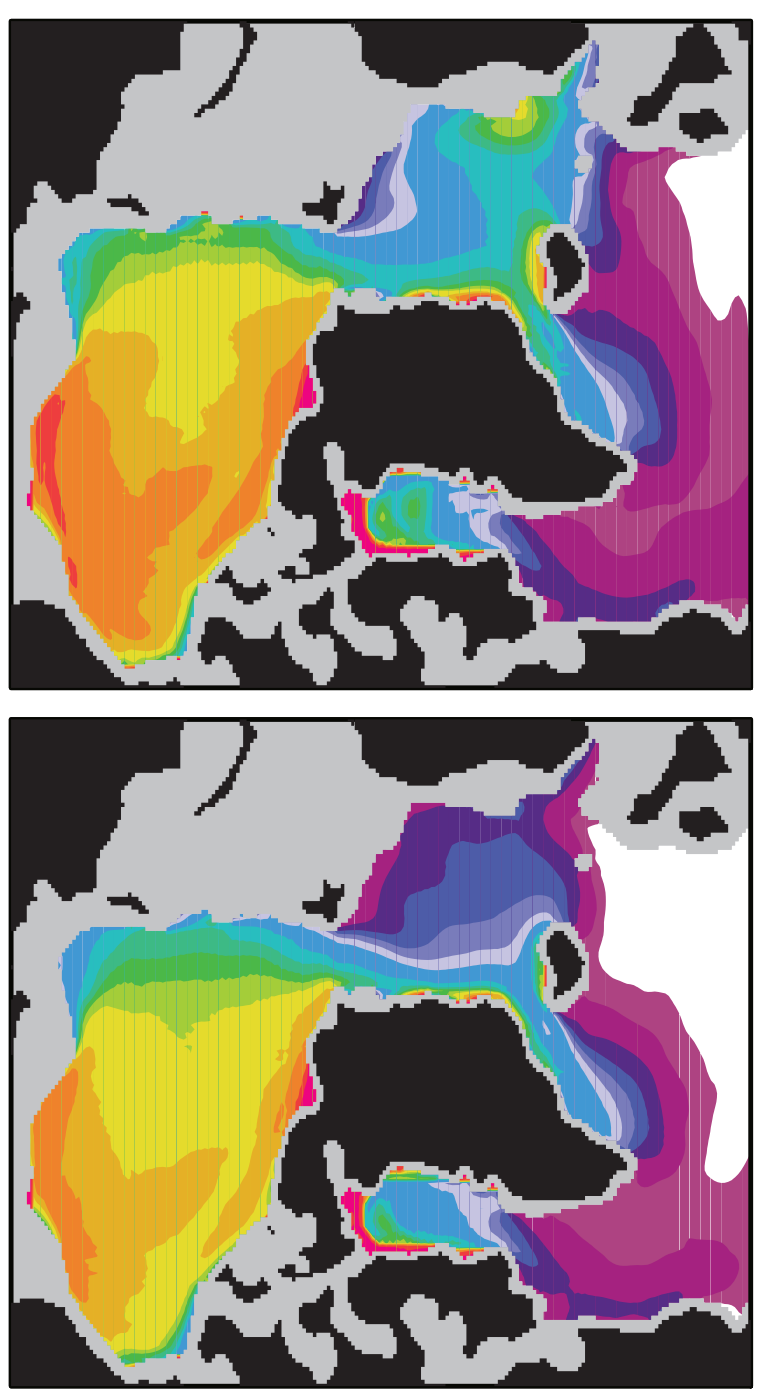


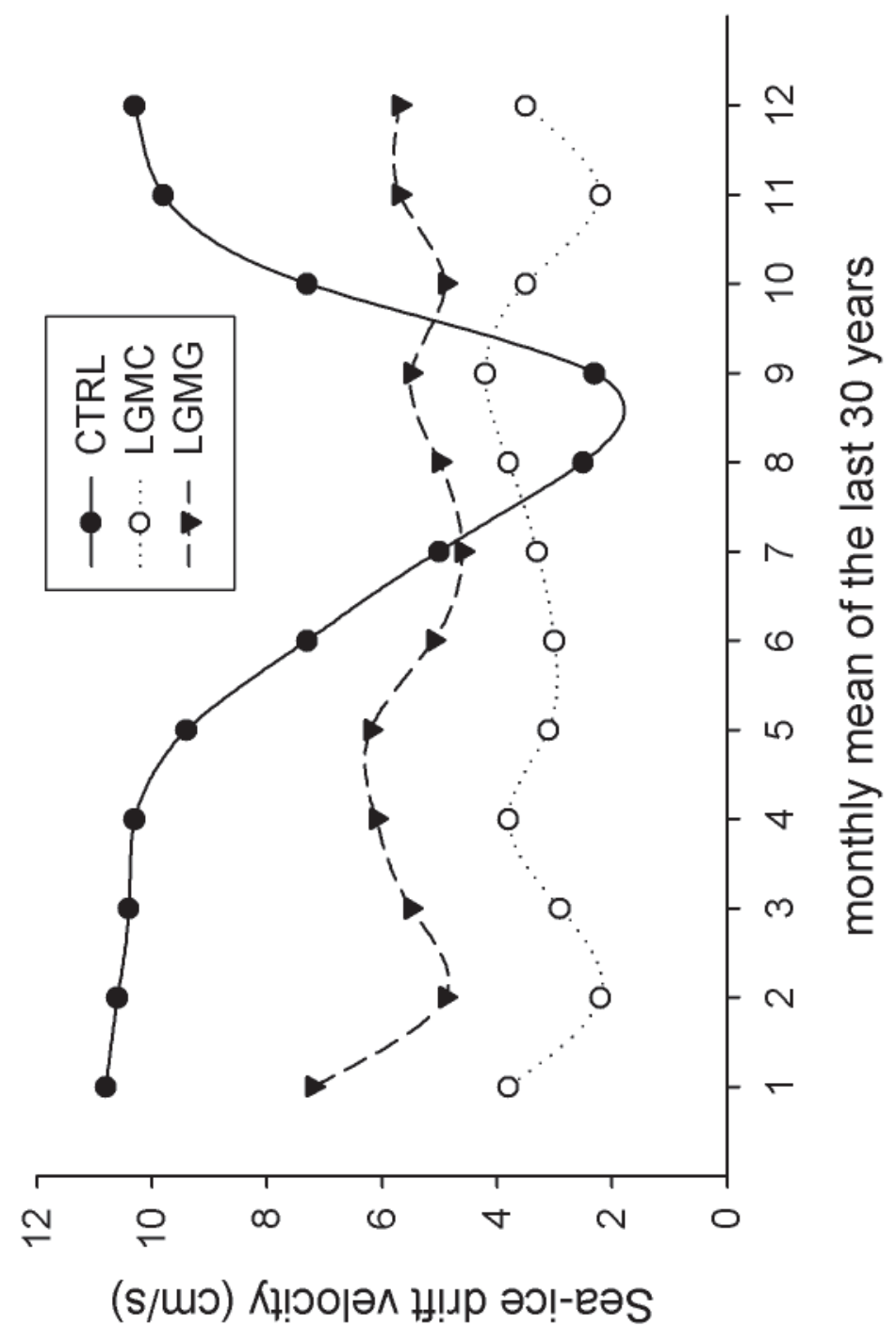




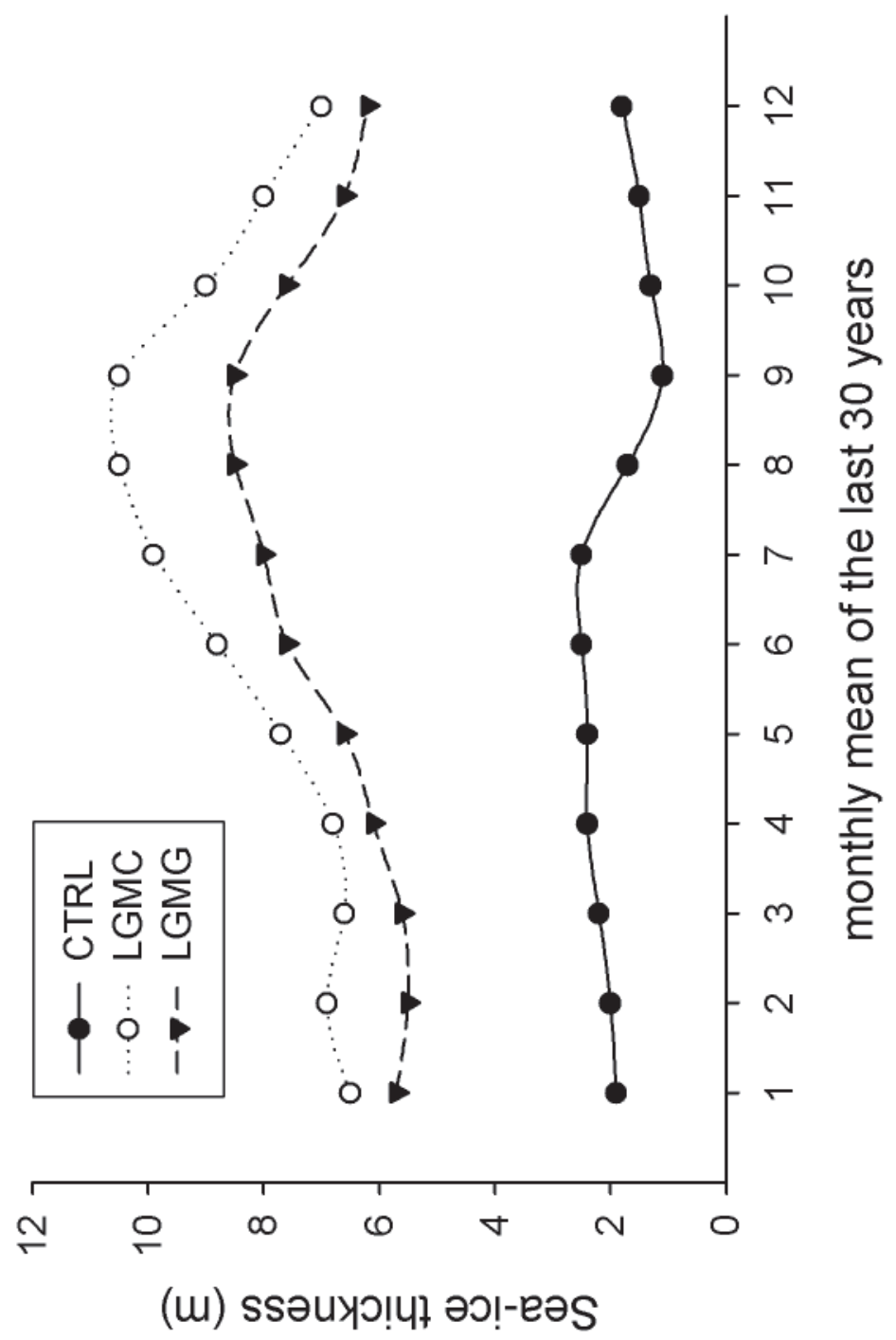


ctrl
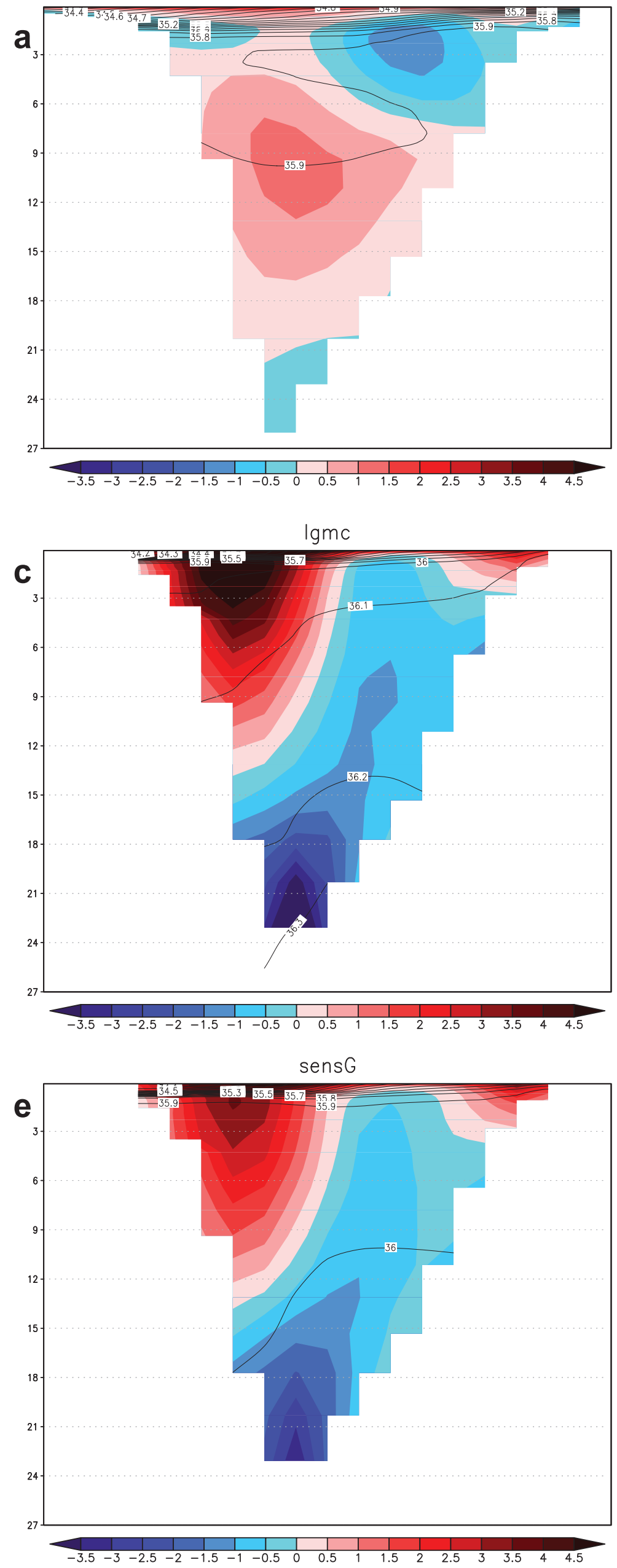

Igmg
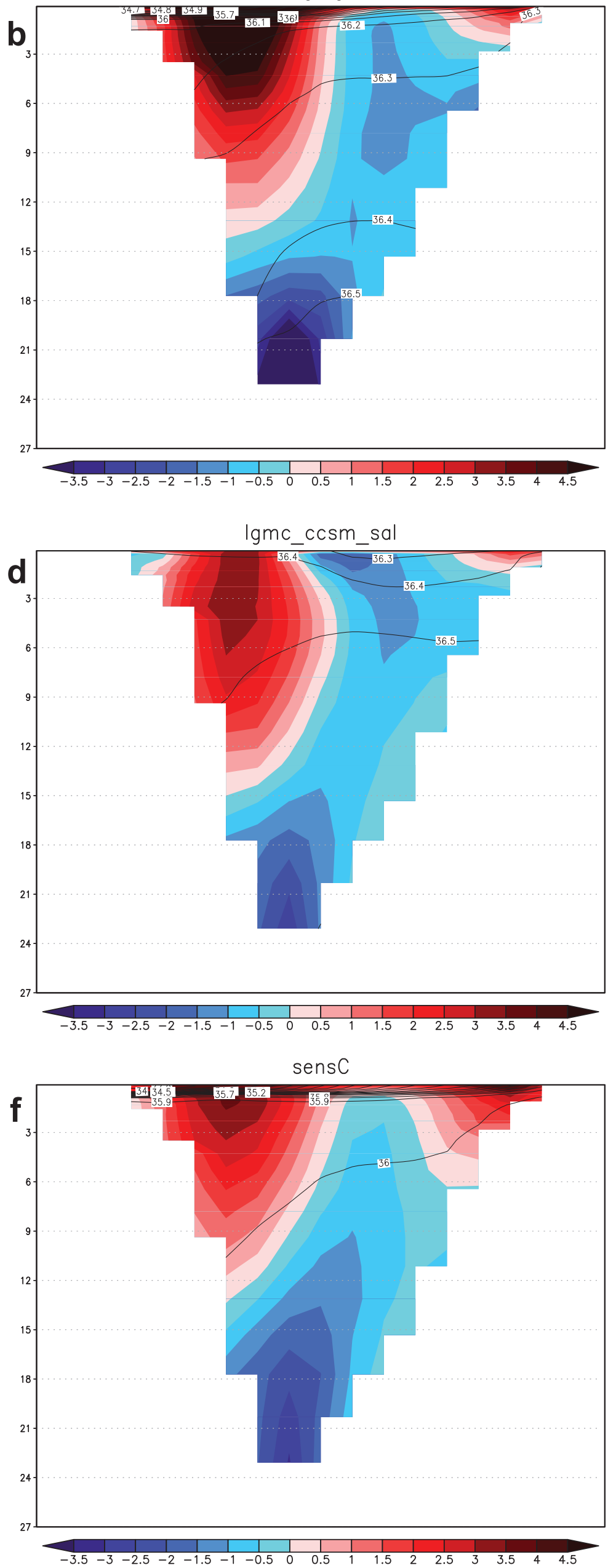
Igmc_0.5psi

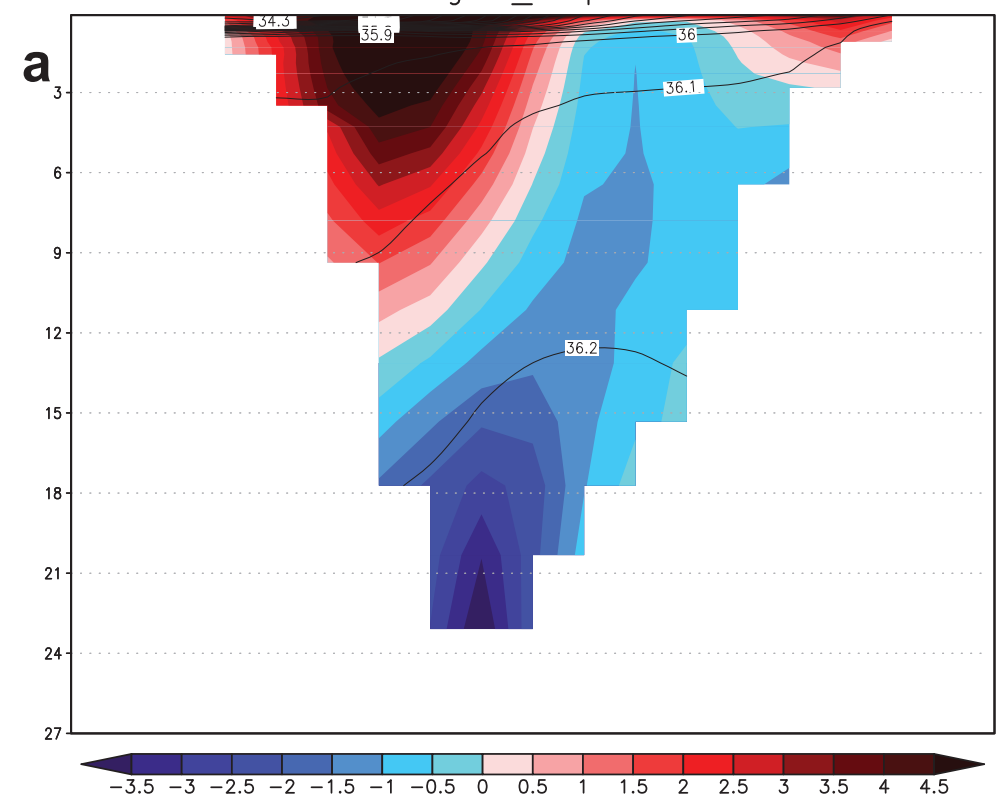

Igmc_1.5psi

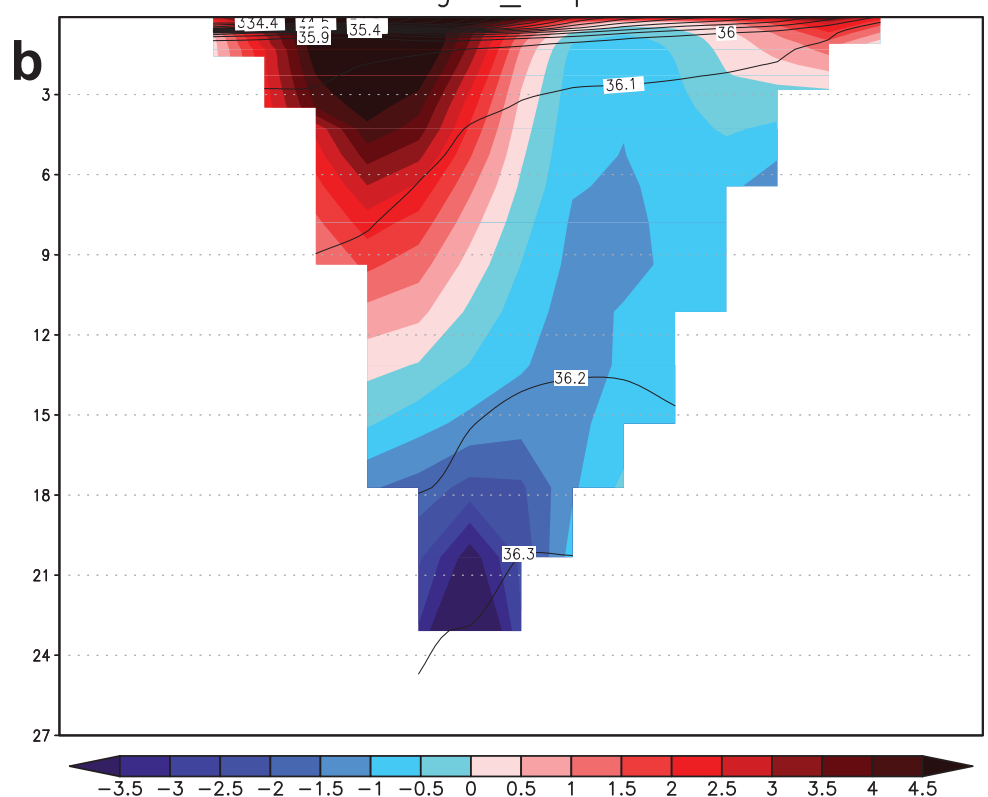

